\title{
GEOCHEMISTRY OF VAPOR-DOMINATED HYDROTHERMAL VENT DEPOSITS IN YELLOWSTONE LAKE, WYOMING
}

\author{
A THESIS \\ SUBMITTED TO THE FACULTY OF THE \\ UNIVERSITY OF MINNESOTA
}

\begin{abstract}
By
Amanda Lee Tudor

IN PARTIAL FULFILLMENT OF THE REQUIREMENTS

FOR THE DEGREE OF

MASTER OF SCIENCE
\end{abstract}

Advisor: Dr. William E. Seyfried, Jr.

July 2020 
(C) 2020 Amanda Lee Tudor 


\section{ACKNOWLEDGEMENTS}

First and foremost, I would like to thank my advisor, Dr. William Seyfried, for all the patience, support, and knowledge you have provided over the past 2 years. Your guidance has allowed me to grow professionally as well as achieve an immense understanding and appreciation of geochemistry. Thank you for this opportunity. Next, I would like to acknowledge those within my committee, Dr. Cara Santelli and Dr. Bruce Moskowitz, for the helpful insight and additional patience. Of course, this all would also not be possible without the NSF funded project Hydrothermal Dynamics of Yellowstone Lake (HDY-Lake) and the collaborators within. Thank you Dr. Dioynsis Foustoukos, Dr. Bruce Moskowitz, Elizabeth Lundstrom, and Liheng Wang, who contributed their time to analyze isotopic, magnetic, and chemical data as well as contribute to modelling, respectfully.

Thanks to those within the Seyfried Lab for helping with this project as well as helping me navigate grad school. Thank you Dr. Chunyang Tan, Dr. Peter Scheuermann, Shichao Ji, Liheng Wang, and Dr. Yanlu Xing. A special thanks to Dr. Andrew Fowler for your mentorship, encouragement, and lively discussions. Additionally, thank you to the University of Minnesota Earth Science graduate student body, administrative staff, and professors for making my time here enjoyable and insightful.

I additionally would like to acknowledge all of those prior to graduate school that have allowed me to be in this position. Dr. Pete Sucsy and Ed Carter, thank you for taking a chance on a Marine Science major. I am enterally grateful. Thank you Dr. Michael Perfit for allowing me to grow as a scientist and discover my love for research. 
Your encouragement, support, and kindness gave me the confidence to continue in academia even when I didn't believe in myself. Colin Krause and those at the Center for Technology Transfer (CATT) thank you for the opportunity to expand my knowledge and gain a greater interdisciplinary background.

And finally, thank you to all of those that have encouraged me throughout the years especially my mom, dad, brother, friends and family. Azia Hill, thank you for your friendship and love throughout the years. And a special thank you to Becca Troast, I couldn't have gotten through grad school without you, especially in a pandemic. 


\begin{abstract}
Yellowstone Lake hydrothermal vent systems have been studied recently in connection with the HD-YLAKE program, a multidisciplinary project investigating the feedback between chemical and physical processes characterizing the sub-lacustrine hydrothermal system. Here we focus on the chemical and mineralogical composition of deposits/alteration and coexisting vent fluid chemistry associated with Stevenson Island Deep Hole vents. Remote in its location, at $120 \mathrm{~m}$ below lake level, Stevenson Island Deep Hole vents provide an excellent natural laboratory to assess fluid-mineral interaction and phase separation phenomena that contribute to the chemical evolution of a particularly active region of the lake floor hydrothermal system. Hydrothermal fluids issuing from Stevenson Island Deep Hole are enriched in dissolved $\mathrm{H}_{2} \mathrm{~S}$ and $\mathrm{CO}_{2}$, enhancing mass transfer reactions and transforming diatomaceous sediment, which primarily lines the Yellowstone Lake basin floor, to an assemblage characterized by kaolinite, boehmite or smectite, and pyrite. Accordingly, this process results in significant volume loss up to $80 \%$. Theoretically, this may contribute to the conical depressions which define the Stevenson Island vent system. Kinetic consideration are consistent with this interpretation. Hot water discharged (demonstrated by 1D modelling) from the system to lacustrine sediment simulates amorphous silica and quartz dissolution increasing porosity, thus enhancing downward excavation of sediment. This additionally may increase flow, leading to greater amounts of alteration. With the addition of steam derived $\mathrm{H}_{2} \mathrm{~S}$ and $\mathrm{CO}_{2}$, alteration mineralization progresses in the sequence of amorphous silica, quartz, smectite, kaolinite, then boehmite and is intensified with flow volume.
\end{abstract}


Identification of minerals in this alteration sequence in relation to venting proximity is suggestive of a dynamic hydrothermal system with complex fluid networks convectively circulating throughout the subsurface of this area and significant venting that may displace altered sediment. Additionally assessment of deuterium/hydrogen stable isotope data of kaolinite and coexisting vent fluids is most consistent with analogous data from Sheppard and Gilg (1996). The combination of chemical, isotopic, and mineralogical data reported here helps to constrain the spatial and temporal evolution of the sub-lacustrine Stevenson Island vent system in Yellowstone Lake. 


\section{TABLE OF CONTENTS}

Acknowledgements

Abstract

iii

Table of Contents

List of Table

vi

List of Figures

vii

1. Introduction

1.1 Yellowstone Geological Background 1

1.2 Yellowstone Lake 2

2. Methods

2.1 Field Methods and Sample Processing $\quad 7$

2.1.1 Stevenson Island Sediment Samples $\quad 7$

2.1.2 Sample Processing $\quad 8$

$\begin{array}{ll}2.2 \text { Geochemical Analysis } & 10\end{array}$

$\begin{array}{ll}\text { 2.2.1 Major and Trace Element Chemistry } & 10\end{array}$

$\begin{array}{ll}\text { 2.2.2 Deuterium/Hydrogen Stable Isotope } & 10\end{array}$

2.3 Mineralogical Treatment and Analysis $\quad 11$

$\begin{array}{ll}\text { 3. Results } & 13\end{array}$

3.1 Mineralogy 13

3.2 Chemical Alteration $\quad 15$

$\begin{array}{ll}3.3 \text { Deuterium/Hydrogen Isotopes } & 19\end{array}$

4. Discussion $\quad \mathbf{2 0}$

4.1 Fluid-mineral Alteration: Sources and Processes of Hydrothermal Activity 20

4.2 Phase Equilibria Constraints on Mass-Transfer Processes 22

4.3 Reaction Path Modelling 24

4.4 Kinetic Considerations 28

4.5 Acid Metasomatism and Redox Constraints 34

4.6 Isotope Constrains 37

5. Conclusions $\quad 41$

6. References $\quad 44$

7. Appendix $\quad 49$ 


\section{LIST OF TABLES}

Table 1: Mineralogical Composition of Vent Sediments 14

Table 2: Chemical Composition of Vent Sediments 16

Table 3: Deuterium/Hydrogen Isotope Values of Vent Sediment and Fluids 19

Table 4: Unaltered Sediment Composition 27

Table 5: Dissolution Model Constraints and Illustration 30

Table A.1: Sampling Procedures 49 


\section{LIST OF FIGURES}

Figure 1: Stevenson Island Deep Hole, Location and Bathymetry 2

Figure 2: Chemical Composition of Vent Fluid 4

Figure 3: ROV Vent Sediment Core Sampling 7

Figure 4: Sampled Core Images and Relative Locations 9

Figure 5: Mass Balance Chemical Correlations 18

Figure 6: Silica Solubility Diagram $\quad 22$

Figure 7: Reaction Path Modeling: Chemical and Mineralogical Evolution 26

Figure 8: Phase diagram: $\mathrm{MgO}-\mathrm{A} 12 \mathrm{O} 3-\mathrm{SiO} 2-\mathrm{H} 2 \mathrm{O}-\mathrm{HCl}$ system 28

Figure 9: 1D Reactive Transport Modelling Step Results 31

Figure 10: 1D Reactive Transport Modelling Final Results 32

Figure 11: Diatom Aluminum Surface Coating EDS and SEM 33

Figure 12: Pyrrhotite SEM Images 35

Figure 13: Reduction-Oxidation Reaction of Vent System Iron Minerals 36

Figure 14: Kaolinite Formation Constraints in Relation to Fluid Variability 39

Figure 15: Phase Equilibria in the $\mathrm{SiO} 2-\mathrm{A} 12 \mathrm{O} 3-\mathrm{H} 2 \mathrm{O}$ System 40

Figure 16: Conceptual Model: SI Deep Hole Sediment Alteration Progression 42 


\section{INTRODUCTION}

\subsection{Yellowstone Geological Background}

Yellowstone National Park (YNP) is located in Northwestern Wyoming in the United States and has long been recognized as a region of unusually intense volcanic and tectonic activity that is currently centered above the Yellowstone hotspot (Morgan et al., 2009). For the past $17 \mathrm{Ma}$ the hot spot has generated a $700 \mathrm{~km}$ northeastward volcanic trending track; a result of the North American plate migration. (Morgan et al., 2009a; Pierce and Morgan,1992; Christiansen 2001). Evidence of this can be found in the sequence of subsided and extinct silicic volcanic rocks recognized along the Snake River Plain (Morgan and Shanks, 2005; Pierce and Morgan, 2009). The current locus- the Yellowstone Plateau — is geochemically and volumetrically distinct from earlier expression of the hotspot. The Yellowstone Plateau evolved through three episodic caldera forming eruptions, occurring 2.1 Ma, 1.3 Ma, and 0.64 Ma, and erupting more than $3700 \mathrm{~km}^{3}$ of dominantly rhyolitic pyroclastic flows (Christian 1984, 2001, \& Christiansen et al., 2007). Geophysical imaging and the sheer size of features associated with the hot spot are suggestive of a mantle plume exceeding $1000 \mathrm{~km}$ in depth. In the modern day volcanic system, this has generated mafic melt in the lower crust, which successively produced a $5-16 \mathrm{~km}$ deep rhyolitic melt in the upper crustal zone (Huang et al., 2015; Pierce and Morgan 2009). Concentrated within the boundaries of the 0.64 Ma Yellowstone Caldera- heat and non-condensable gases from the underlying crystallizing magma reservoir interact with deeply circulating meteoric water to produce extensive and geochemically diverse expressions of hydrothermal activity (Hurwitz and Lowenstein 2014, Fournier 1989). 


\subsection{Yellowstone Lake}

The northern two-thirds of Yellowstone Lake resides on the southeast margin of the 0.64 Ma Yellowstone Caldera (Fig.1A). Although Yellowstone Lake represents a relatively small area, it still accounts for $\sim 10 \%$ of the total flux of hydrothermally derived components into Yellowstone National Park (YNP) overall (Morgan and Shanks, 2005).
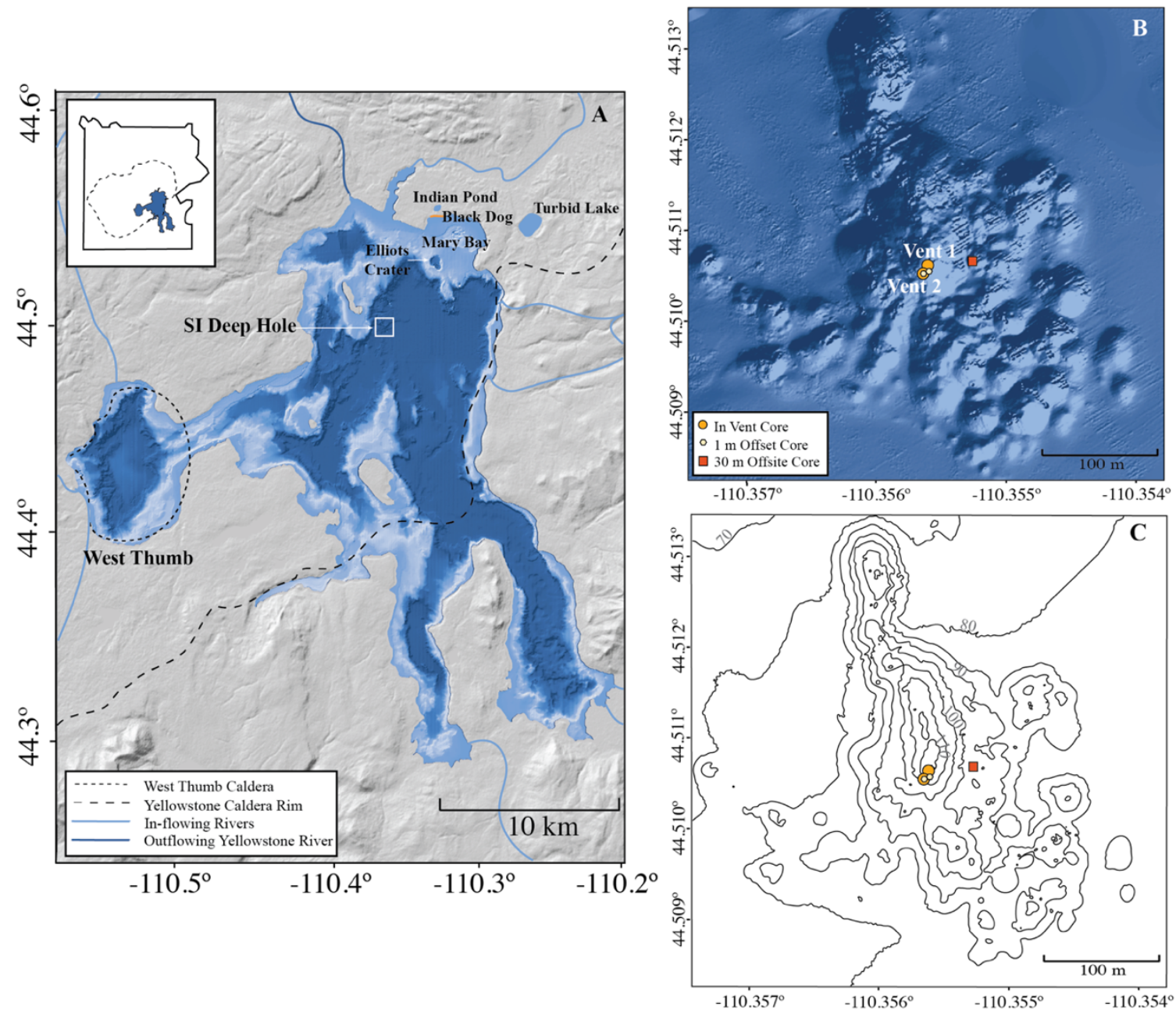

Figure 1. Location of SI Deep Hole in Yellowstone Lake, Wyoming. (A) Yellowstone Lake. Bathymetric lake-wide data from Morgan et al., (2007a) and Morgan et al., (2007b). Caldera margins form Christiansen (2001). North basin hydrothermal areas from Morgan et al., (2019b). River data from Koel, (2010) (B) Stevenson Island Deep Hole vent field. (C) Stevenson Island Deep Hole vent field bathymetry with depth contour lines. SI Deep Hole AUV data from Sohn et al., (2017). 
The $341 \mathrm{~km}^{2}$ basin — uniquely shaped by volcanic, glacial, and hydrothermal activity —is geologically diverse, composed largely of Quaternary rhyolitic flows, glacial deposits, and lake sediment; with the upper sequence of unaltered basin floor primarily consisting of laminated fine grained deep-basin lacustrine sediments, containing significant amounts of diatomaceous material (Morgan et al., 2009b; Johnson et al., 2003). Hydrothermal explosion craters and deposits occupy the lake shores and basin emphasizing the necessity to understand the vent systems within the lake (Morgan and Shanks 2005; Morgan et al., 2009b). Sensitive to environmental and geological processes, Yellowstone Lake sub-lacustrine hydrothermal systems have recently been investigated as a part of an interdisciplinary NSF study -"Hydrothermal Dynamics of Yellowstone Lake" (HDYLake). ROV operations conducted as part of the study have collected hydrothermal deposits and vent fluid samples, previously deemed inaccessible (Sohn et al., 2017; Tan et al., 2017). The hydrothermal system located within the Deep Hole area east of Stevenson Island (SI Deep Hole) is a complex system of particular interest, and is the main focus of this report.

At $\sim 120 \mathrm{~m}$ depth, the unusually high temperature hydrothermal fluids issuing from vents on the floor of SI Deep Hole provide insight on heat and mass transfer processes that are difficult or impossible to study elsewhere in Yellowstone National Park. The northwest trending fissures recognized from ROV observations and from earlier high resolution bathymetric data (Johnson et al., 2003; Morgan et al. 2003), likely account for the depth of the lake floor in the Deep Hole region. The fissures may also play a role in focusing flow of hydrothermal fluids, enhancing alteration and mass transport, and actually shaping the bathymetric expression of the lake floor in this area of 


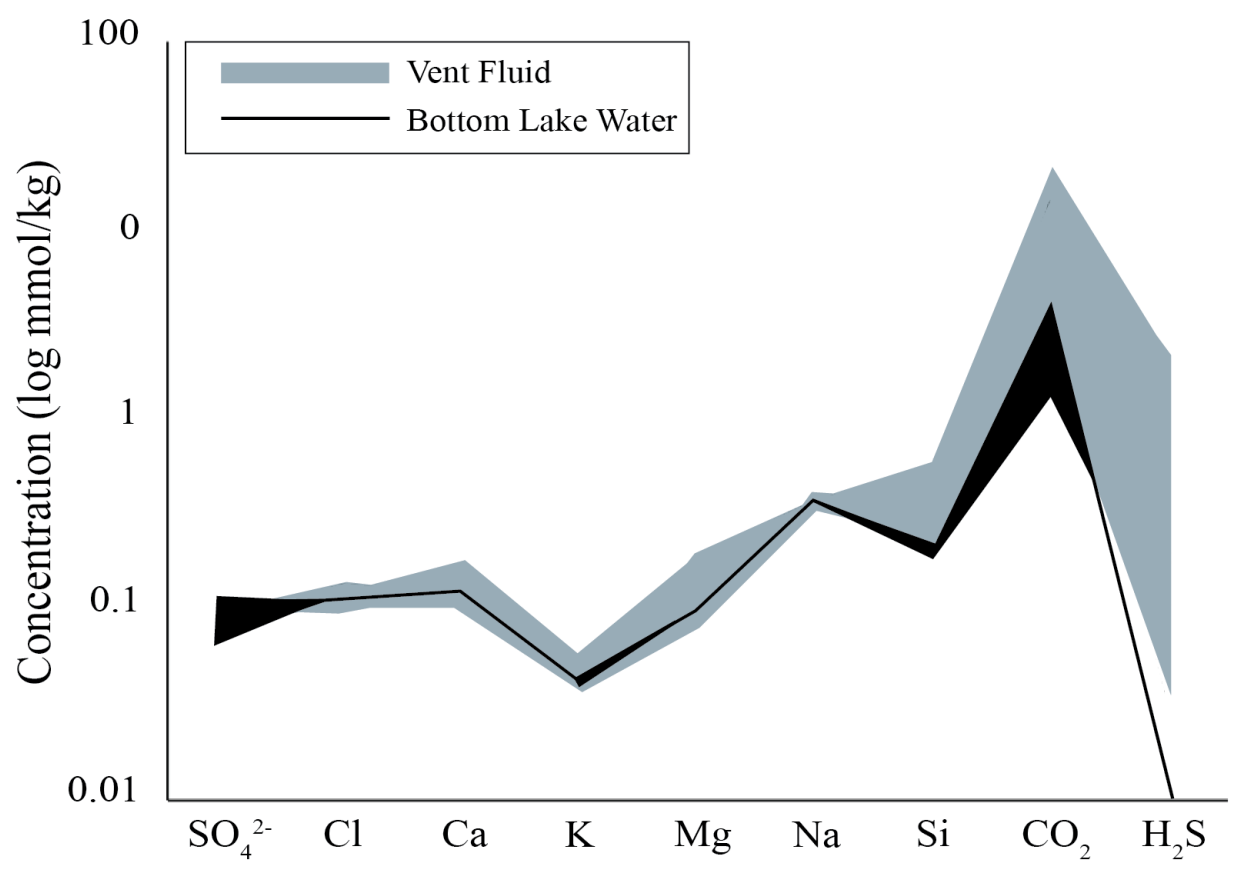

Figure 2. Chemical composition of SI Deep Hole venting fluid compared to bottom lake water, emphasizing magmatic gas addition of $\mathrm{CO}_{2}$ and $\mathrm{H}_{2} \mathrm{~S}$. Chemical data is available in Fowler et al., 2019c Table 2. $\mathrm{CO}_{2}$ value is the sum of $\mathrm{HCO}_{3}{ }^{-}$and $\mathrm{CO}_{2}$.

Yellowstone Lake (Fig. 1C). Thus, vent fluids issuing from this region of the lake floor produce a recognizable thermal anomaly, which in turn suggests a vent fluid flux of 1.4 $\times 10^{3} \mathrm{~kg} / \mathrm{s}$ and heat flux of $20-50 \mathrm{MW}$ (Sohn et al., 2019). The hydrothermal vents, present within SI Deep Hole, are among the hottest sub-lacustrine vents to be reported anywhere in the world, with in-situ temperatures of $174^{\circ} \mathrm{C}$ (Fowler et al., 2019a, 2019c). Described as 5-10 cm non-constructional orifices (Fig. 3A), SI Deep Hole hydrothermal vents issue fluids that not only achieve high temperatures, but are also $\mathrm{CO}_{2}$ saturated, as suggested by thermodynamic calculations and the observations of $\mathrm{CO}_{2}$ bubble separating from fluids issuing from vents on the lake floor (Fowler, 2019a, Tan et al., 2019).

The unique nature of the composition and temperature of the venting fluid is suggestive of a steam-heated hydrothermal system (Fowler et al., 2019a, White et al., 
1971). Thus, the SI hydrothermal vent fluids in the Deep Hole region are mixtures of high enthalpy steam and lake bottom water. In addition to providing heat, the steam carries with it high concentrations of $\mathrm{CO}_{2}$ and $\mathrm{H}_{2} \mathrm{~S}$, while also contributing condensate, which dilutes the lake water in proportion to magnitude of steam addition (Fig. 2). The occurrence of a hydrothermal system such as this is possible due to an overlying lowpermeability substrate acting as a sediment cap to a more permeable reservoir (Fowler et al., 2019a, c). In general, a sediment caprock of low permeability, allows steam to escape, while minimizing the influx and quench effects of the ambient lake water (Raharjo et al., 2016; Schubert et al., 1980). Thus, the high enthalpy vapor transfers heat by conduction and advection to the overlying lake water, broadly analogous to heat transfer processes for some subaerial hot springs and fumaroles observed elsewhere in YNP (Hurwitz and Lowenstein 2014). Vapor-dominated subaerial systems are often recognized by noteworthy acidity and high sulfate concentrations (Truesdell et al., 1973; Rowe et al., 1973; Hurwitz and Lowenstein 2014). This is not the case, however, for sub-lacustrine Stevenson Island vent fluids owing to the general absence of dissolved oxygen, and acidity is provided entirely by hydrolysis of dissolved $\mathrm{CO}_{2}$ (Fowler et al., 2019c; Sohn et a., 2017). Thus, sub-lacustrine hydrothermal systems at Stevenson Island in Yellowstone Lake might provide a better representation of chemical reactions that may occur within subaerial systems, but at depths hundreds of meters below the land surface (Fowler et al., 2019c).

Here we focus on the composition of coexisting minerals and fluids sampled from active and inactive vents in the SI area of Yellowstone Lake. To accomplish this, we make use of comprehensive dataset using chemical, isotopic, and physical parameters, 
which together provide an accurate picture of heat and mass transfer processes.

Accordingly, information of this sort helps to constrain the chemical and mineralogical evolution of the Stevenson Island sub-lacustrine hydrothermal system in time and space. 


\section{METHODS}

\subsection{Field Methods and Sample Processing}

\subsubsection{Stevenson Island Sediment Samples}

Deep Hole sediment sampling was conducted in August of 2017 and 2018. To accomplish this, the remotely operated vehicle (ROV) "Yogi" and support ship (R/V Annie), operated by the Global Foundation for Ocean Exploration, were utilized. Equipped with a 5-function electric manipulator for fluid and sediment sampling, 90001m LED lights, and multiple high definition cameras, ROV "Yogi" sampled sediments through the use of push cores (Fig 3). These are 2-inch diameter stainless steel tubes, attached by ball-handle to the ROV manipulator. In some cases, penetration of sediment
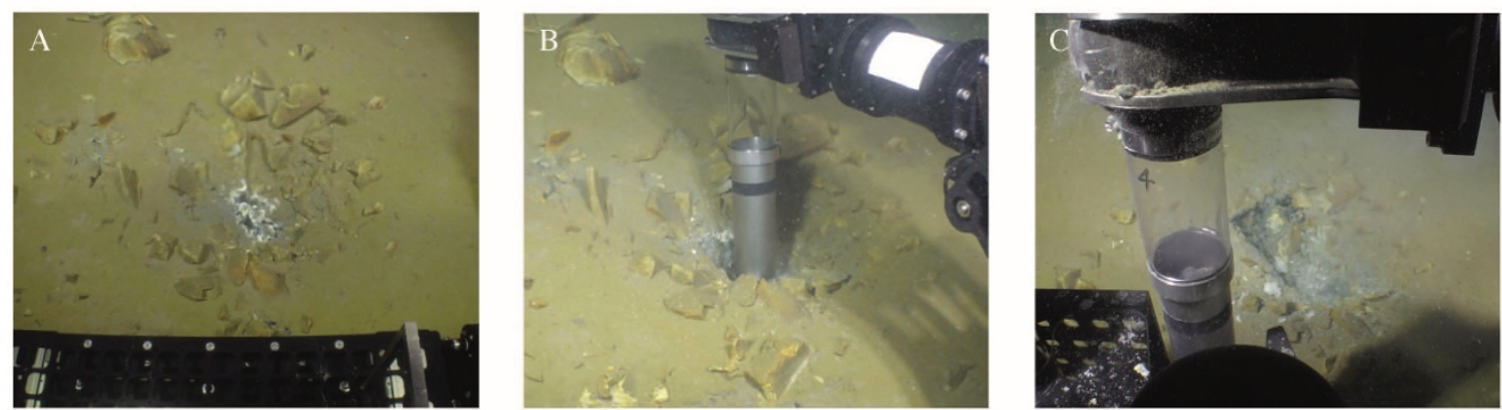

Figure 3. (A) Vent 1 within Stevenson Island Deep Hole (B) Push core sampling of Vent 1.(C) Push core recovery.

proved difficult and required additional force exerted by ROV thrusters. Push core samples, measuring 6-22 cm long, were obtained from several localities in the vent and near vent region of the lake floor at SI Deep Hole. Cores (YL17U03I and YL17U04, YL17U01and YL17U02) were acquired from active vent sites 1 and 2, respectively. Additionally, a single push core (Y117U05) was taken approximately 30 meters away from the active venting area (Fig 1B). Upon return to R/V Annie, the samples were transferred to a freezer on the vessel and stored in polycarbonate containers. Samples 
were later processed at the National Science Foundation (NSF) LacCore facility at the University of Minnesota.

\subsubsection{Sample Processing}

Cores were first split in half with a medical cast saw, utility knifes, and high-test fishing line to more clearly reveal textural characteristics. Digital images were then obtained with a DMT (CoreScan Colour), which processes images by line-scan CCD camera (Fig. 4). Inherently heterogeneous, cores were then subsampled at the University of Minnesota (UMN) Geochemistry Laboratory to acquire a broad chemical perspective. This includes sampling of material from the bottom, middle, and top of the respective cores (Fig. 4). Cores taken from active vent sites were subsample at the bottom, to provide a better understating of compositional variability with core depth. Offset cores (1 $m$ displaced from the vent) display vertical variability and thus were subsampled in a number of locations within the core. Specific procedures and sample description for each sample are outlined in Appendix (Table A.1). 

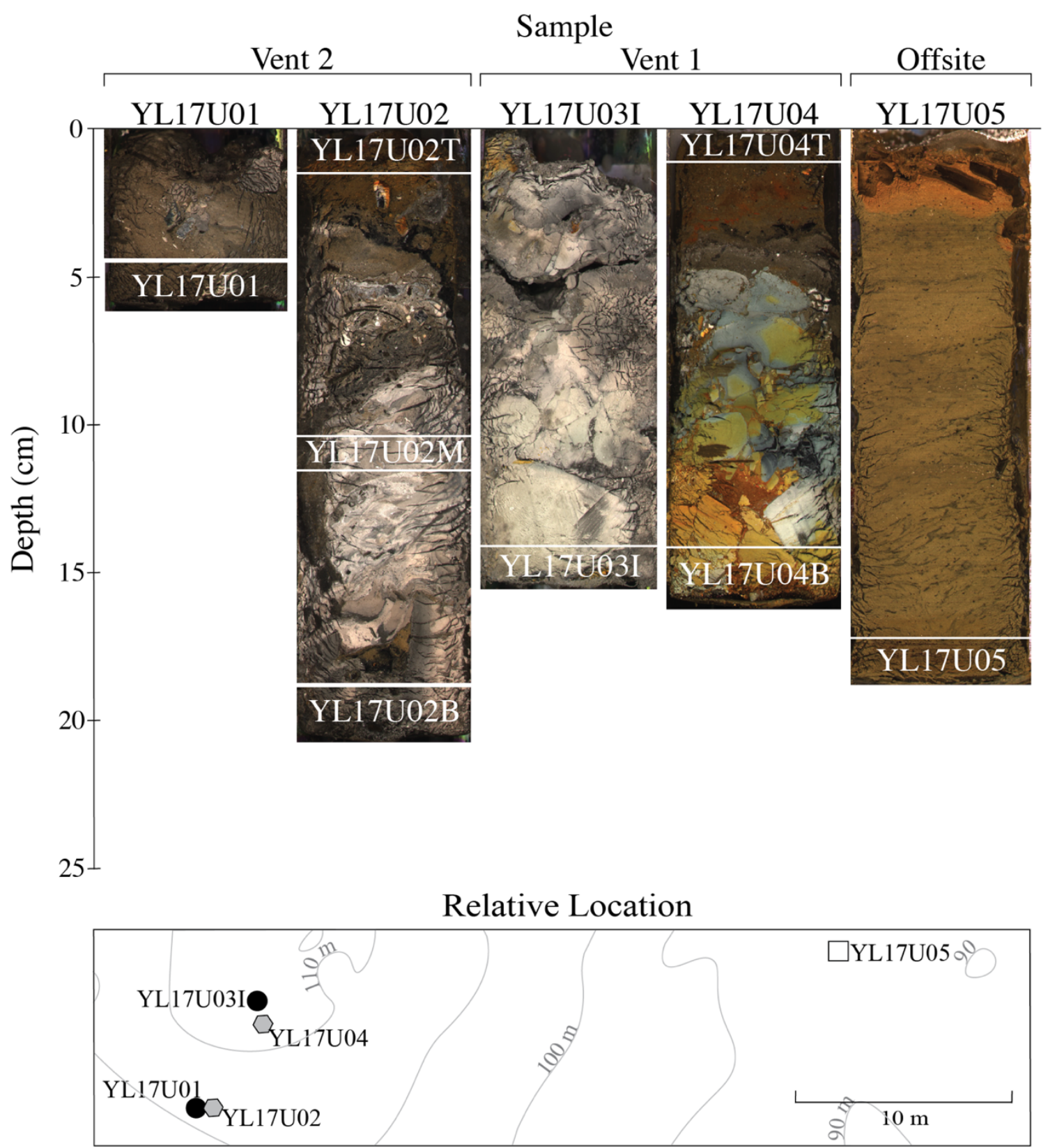

- In Vent Core $\quad 1 \mathrm{~m}$ Offset Core $\square 30 \mathrm{~m}$ Offsite Core

Figure 4. 2017 Core samples displaying depth, textural observations, and relative location on the lake floor. ROV operations collected 5 cores in the SI Deep Hole system, 4 of which from active areas and one $30 \mathrm{~m}$ away. For mineralogical and chemical analysis, subsampling of the cores was necessary. Subsamples displayed in this study are written in white in the core section to which it was taken, this includes YL17U01, YL17U02T, YL17U02B, YL17U03I, YL17U04T, YL17U04B, YL17U05. Suffix are included in the names where there are multiple samples or the sample was collected differently. Where $T, M, B$, and I stand for top, middle, bottom, and insert (core taken to allow increase fluid flow for year long sensor). 


\subsection{Geochemical Analysis}

\subsubsection{Major and Trace Element Chemistry}

Ten core-derived hydrothermally altered sediments were analyzed by ICP-MS (Inductively Coupled Plasma -Mass Spectrometry) and ICP-OES (Inductively Coupled Optical Emission Spectrometry) at the University of Minnesota. The sediment samples were digested in $\mathrm{HF}-\mathrm{HCl}-\mathrm{HNO}_{3}$ at high temperature and high pressure using a titanium supported Teflon lined reactor (see Appendix). Major elements were analyzed using ICPOES, while ICP-MS was used for trace element analysis, optimizing intrinsic capabilities

of these instruments. Analytical uncertainty from replicate measurements were generally $\pm 5 \%$ for reported concentration of major elements and $\pm 10 \%$ for selected trace elements.

Total sulfur of sediment samples (reported as $\mathrm{SO}_{3}$ ) was determined by X-ray fluorescence (XRF) at the Carnegie Institute for Science Earth and Planets Laboratory. Duplicate measurements display standard deviation $(1 \sigma)$ up to $\pm 0.3 \%$. Structural water (hydroxyl) determinations were made with Thermal Conversion Elemental Analyzer (TC/EA). This instrument releases water from sediment minerals by pyrolysis then quantifies this by gas chromatography and mass spectrometry techniques. With duplicate analysis uncertainty does not exceed $\pm 0.4 \%$ on any samples. Total water measurements were determined at the Carnegie Institute.

\subsubsection{Deuterium/Hydrogen Stable Isotopes}

Deuterium/Hydrogen $(\mathrm{D} / \mathrm{H})$ isotope analysis of structural water in altered sediments was also performed at the Carnegie Institute for Science Earth and Planets Laboratory. Samples were dried at $90^{\circ} \mathrm{C}$ for 7 days, then transferred to an Isotope Ratio Mass Spectrometer (Thermo Finnigan Delta ${ }^{\text {Plus }}$ XL), while flushing with He for 2 hours 
to eliminate atmospheric contaminants. $\mathrm{H}_{2}$ reference gas of known $\delta \mathrm{D}$ composition ($123.39 \%$ SMOW) was used for standardization. Calibrations were performed with internal working gas standards derived from the reference gas and analyzed at regular intervals to monitor the accuracy of the measured isotopic ratios and elemental compositions throughout the run. House standards were calibrated against international (SMOW, NBS-22, air) and commercially certified standards from Isoanalytical, USGS, NBS and Oztech. An $\mathrm{H}_{3}{ }^{+}$correction was determined and applied to the hydrogen measurements. Hydrogen stable isotope data are reported in standard delta notation $(\delta \mathrm{A})$ expressed as:

$$
\delta \mathrm{A}(\% \mathrm{o})=\left[\frac{\left(R_{S}-R_{S T D}\right)}{R_{S T D}}\right] \times 1000
$$

where $R_{S}$ and $R_{S T D}$ are the isotope ratios of the sample and the standard, respectively. Isotopic and elemental analysis uncertainties correspond to a standard deviation $(1 \sigma)$ between replicate analysis of distinct subsamples $(n>2)$. Measured analytical uncertainty vary from $\pm 0 \%$ to $\pm 0.4 \%$, dependent on sample.

\subsection{Mineralogical Treatment and Analysis}

Mineralogy of altered sediment samples was determined by a Rigaku MiniFlex, XRD in the Department of Earth and Environmental Sciences at the University of Minnesota. These same samples were also studied using Hitachi TM1000 Tabletop Scanning Electron Microscope (SEM), at the NSF-LacCore facility to determine presence of accessory minerals. XRD measurements, with the exception of YL17U02M, were done by bulk sample sediment analysis. YL17U02M was separated to fines by gravitational settling in water to obtain a more concentrated SI Deep Hole kaolinite standard. To confirm the kaolinite-rich nature of all samples, sediments were subjected to 
both heating $\left(550^{\circ} \mathrm{C}\right.$ for 2 hours $)$ and treatment with ethylene glycol. All XRD measurements were carried out at scan speeds of $1^{\circ} 2 \theta$ per minute, sampling width of $0.02^{\circ}$, and $2 \theta$ scan range between $5^{\circ}$ and $65^{\circ}$ using a cobalt K- $\alpha$ source. Accessory mineral identification required grain size separation; however, efforts were largely focused on the coarse sediment fraction. SEM backscatter electron measurements (BSE) were conducted to provide qualitative information about mineral compositional variability on a fine scale. These data in conjunction with XRD were found to be especially useful for evaluation of both sulfide and silicate minerals, including compositional changes associated with diatom recrystallization reactions. 


\section{RESULTS}

\subsection{Mineralogy}

Sediment cores within the Deep Hole region (YL17U01-YL17U04) reveal broadly similar mineralogical composition, although some variability was noted with depth and location in individual cores (Table 1). Importantly, the crystallinity of individual minerals likely plays a key role in the inferred abundance from XRD data, either resulting in over or under expression of the actual abundance (Fisher and Underwood 1995). Previous investigations (Fowler et al., 2019c) have documented that kaolinite is the dominant silicate mineral associated with SI vent mineralization, in good agreement with results of the present study.

Progression of alteration mineralization in relation to depth in the cores and proximity to venting fluids is as follows: amorphous silica, kaolinite + smectite, and kaolinite + boehmite. Noteworthy differences in this progression, however, do occur, and might be best accounted for by on-going detrital sedimentation from distal sources as well as nearby venting, which may expel altered products such as kaolinite, boehmite, or smectite from some depth within the vent into the bottom lake water, where it is deposited subsequently. The upper portions of some cores (YL17U02 and YL17U04) characterized by the coexistence of diatomaceous (silica-rich) and kaolinite + boehmite (silica-poor) sediments, provides evidence of this. ROV observations, by equipped camera, at vents show particle dispersion into the water column, interpreted as altered mineral, thus confirming the phenomena described above (Fowler et al., 2019c). Diatom sedimentation is significant in surficial deposits throughout Yellowstone Lake and often expressed in the form laminar bedding at the very tops of push cores off set from active 
Table 1. Vent sediment composition measured by XRD and observed by SEM.

\begin{tabular}{|c|c|c|c|c|c|c|c|}
\hline \multirow[t]{2}{*}{ Sample } & \multicolumn{6}{|c|}{ XRD } & \multirow{2}{*}{$\begin{array}{c}\text { Comments } \\
\text { SEM }\end{array}$} \\
\hline & Kao & Boh & Smc & $\overline{Q z}$ & $\mathbf{P y}$ & Al/An & \\
\hline YL17U01 & $\mathrm{xx}$ & $\mathrm{X}$ & & $\mathrm{xx}$ & $\mathrm{x}$ & $\mathrm{X}$ & Framboidal and cubic pyrite present. Diatoms present. \\
\hline YL17U02T & $\mathrm{x}$ & $\mathrm{xx}$ & & $\mathrm{X}$ & $\mathrm{xx}$ & & Additional presence of K-feldspar. \\
\hline YL17U02M & $\mathrm{xx}$ & & & & - & & Kaolinite \\
\hline YL17U02B & $\mathrm{xx}$ & $\mathrm{X}$ & - & $\mathrm{x}$ & $\mathrm{Xx}$ & & High concentration of pyrite. \\
\hline YL17U03I & $\mathrm{xx}$ & - & $\mathrm{xx}$ & $\mathrm{xx}$ & - & & $\begin{array}{l}\text { Pyrrhotite dominant with presence of pyrite and trace amounts of } \\
\text { chalcopyrite, sphalerite, and possible siderite. }\end{array}$ \\
\hline YL17U04T & $\mathrm{x}$ & $\mathrm{xx}$ & & $\mathrm{x}$ & $\mathrm{x}$ & & Large pyrite clusters. Diatoms present. \\
\hline YL17U04B & $\mathrm{xx}$ & & $\mathrm{xx}$ & $\mathrm{X}$ & - & & Smectite rich. \\
\hline YL17U05 & $\mathrm{x}$ & & $\mathrm{XX}$ & $\mathrm{x}$ & & $\mathrm{xX}$ & Majority diatom. \\
\hline $\begin{array}{l}\mathrm{xx}=\text { Major } \\
\mathrm{x}=\text { minor } \\
-=\text { trace }\end{array}$ & & & & & & & \\
\hline
\end{tabular}


vent sites. Diatom abundance, however, dramatically decreases with depth and is replaced with quartz, which is thermodynamically favorable in vent fluid. Quartz and kaolinite are detected in all cores, with the exception of YL17U02M.

Mineralogical differences between push cores, may also vary as a result of vent specific differences in the temperature and chemistry of respective vent fluids, which can serve as primary constraints on the composition of minerals at depth. These differences have been documented previously by Fowler et al. (2019a). Although some of the differences reflect the degree of mixing and cooling at the time of sampling, more fundamental differences in redox and $\mathrm{pH}$, caused by corresponding differences in $\mathrm{H}_{2} \mathrm{~S}$ and $\mathrm{CO}_{2}$ vapor source fluids, undoubtedly play a role as well. It is not surprising, therefore, that mineralization of the primary vent sites are qualitatively different, especially involving sulfide and oxide minerals (Table 1).

Reference core (YL17U05), which as emphasized earlier, is located outside the area of present hydrothermally activity, contains abundant diatomaceous material, together with minor amounts of smectite, kaolinite, boehmite, quartz, albite, and anorthite. The clay minerals are likely hydrothermal in origin and transported by currents to this off-site location, while feldspar minerals and possibly quartz are almost certainly detrital.

\subsection{Chemical Alteration}

The major and trace element chemistry of variably altered sediment samples from the SI Deep Hole area of Yellowstone Lake are listed in Table 2. In general, samples from within or very near vent sites tend to be enriched in $\mathrm{Al}_{2} \mathrm{O}_{3}$ ( 20 to 28 wt.\%), while containing $\mathrm{SiO}_{2}$ ( 34 to 50 wt. \%) and $\mathrm{H}_{2} \mathrm{O}$ ( 9 to 12 wt.\%) in amounts consistent with the 
Table 2. SI Deep Hole sediment analytical data.

\begin{tabular}{|c|c|c|c|c|c|c|c|c|}
\hline & $\underline{\text { YL17U01 }}$ & $\underline{\text { YL17U02T }}$ & $\underline{\text { YL17U02M }}$ & $\underline{\text { YL17U02B }}$ & $\underline{\text { YL17U03I }}$ & $\underline{\text { YL17U04T }}$ & $\underline{\text { YL17U04B }}$ & $\underline{\text { YL17U05 }}$ \\
\hline $\mathrm{Na}_{2} \mathrm{O}$ & 0.65 & 0.91 & -- & 1.1 & 0.32 & 0.07 & 0.47 & 1.0 \\
\hline MgO & 0.83 & 0.98 & 0.70 & 0.59 & 5.2 & 0.63 & 6.0 & 1.7 \\
\hline $\mathrm{Al}_{2} \mathrm{O}_{3}$ & 26 & 25 & 39 & 26 & 28 & 26 & 28 & 13 \\
\hline $\mathrm{SiO}_{2}$ & 50 & 41 & 39 & 35 & 45 & 34 & 42 & 62 \\
\hline $\mathbf{P}_{2} \mathbf{O}_{5}$ & 0.18 & 0.32 & 0.13 & 0.13 & 0.57 & 0.32 & 1.2 & 0.21 \\
\hline $\mathrm{SO}_{3} *$ & 3.0 & 2.8 & 3.3 & 10 & 1.7 & 5.2 & 0.080 & -- \\
\hline $\mathbf{K}_{2} \mathbf{O}$ & 0.69 & 0.59 & 0.26 & 0.36 & 0.20 & 0.41 & 0.22 & 1.1 \\
\hline $\mathrm{CaO}$ & 0.64 & 0.67 & 0.18 & 0.42 & 1.2 & 0.52 & 1.8 & 1.4 \\
\hline $\mathrm{TiO}_{2}$ & 0.97 & 0.84 & 1.0 & 0.91 & 1.0 & 0.93 & 1.2 & 0.51 \\
\hline MnO & 0.015 & 0.03 & 0.0 & 0.01 & 0.11 & 0.02 & 0.16 & 0.028 \\
\hline $\mathrm{Fe}_{2} \mathrm{O}_{3}$ & 5.5 & 10 & 2.9 & 20 & 6.1 & 14 & 8.7 & 3.3 \\
\hline $\mathrm{H}_{2} \mathrm{O}$ & 10 & 11 & 13 & 9.2 & 11 & 11 & 12 & -- \\
\hline Total & 99 & 94 & 100 & 104 & 101 & 92 & 101 & 84 \\
\hline $\mathbf{B a}$ & 330 & 289 & -- & 117 & 79 & 200 & 99 & 633 \\
\hline $\mathbf{L i}$ & 3.3 & 0.87 & -- & 3.0 & 0.97 & 1.1 & 4.4 & 0.53 \\
\hline $\mathbf{S r}$ & 119 & 119 & -- & 49 & 62 & 84 & 68 & 266 \\
\hline Ge & 6.2 & 7.7 & -- & 5.5 & 1.1 & 7.0 & 4.6 & 11 \\
\hline $\mathbf{Z r}$ & 337 & 299 & -- & 371 & 267 & 271 & 330 & 185 \\
\hline Nb & 28 & 23 & -- & 27 & 20 & 23 & 23 & 16 \\
\hline Mo & 30 & 26 & -- & 14 & - & 51 & 7.8 & 16 \\
\hline Ln & 0.13 & 0.14 & -- & 0.17 & 0.10 & 0.13 & 0.12 & 0.067 \\
\hline Sn & 3.3 & 2.6 & -- & 3.3 & 1.8 & 3.2 & 2.8 & 2.0 \\
\hline Sb & 15 & 14 & -- & 9.6 & 0.87 & 19 & 2.2 & 12 \\
\hline Te & 0.26 & 0.11 & -- & 0.10 & 0.046 & 0.10 & 0.071 & 0.047 \\
\hline Hf & 9.0 & 7.8 & -- & 9.2 & 7.2 & 8.2 & 8.3 & 5.1 \\
\hline Ta & 1.6 & 1.3 & -- & 1.6 & 1.1 & 1.4 & 1.3 & 0.94 \\
\hline $\mathbf{W}$ & 84 & 115 & -- & 34.2 & 20 & 143 & 49 & 56 \\
\hline Au & - & - & -- & - & - & - & 0.15 & - \\
\hline
\end{tabular}

* Measured by XRF

-- Not Measured

- Not detected

YL17U02M was measured entirely by XRF

abundant presence of kaolinite (Fig. 5B). This is particularly obvious for sample YL17U02M, where SiO2:Al2O3:H2O wt. \% proportions are nearly identical to that of this mineral. Alteration progression of vent sediments can be depicted by immobile element correlation (Grant 2005). Immobile element ratios involving $\mathrm{Al}_{2} \mathrm{O}_{3}$ and $\mathrm{TiO}_{2}$ indicate large scale mass and volume changes relative to the inferred protolith (Fig 5A). The relationship between river load sediment and sediment inferred to represent relatively unaltered sediment in the Deep Hole region, suggests the combination of detrital sediment and diatomaceous silica (silica mass gain of 33\%) best represents the 
protolith prior to hydrothermal alteration (Fig. 5B). Thus, mass loss, relative to the inferred protolith, overwhelmingly involves large scale removal of the sediment silica fraction, a result in keeping with the composition of the acid generating capacity of the vapor-dominated vent fluids (Fowler et al., 2019a) (Fig. 5B).

The elevated $\mathrm{H}_{2} \mathrm{~S}$ concentrations of the hydrothermal vent fluid (Fowler et al., 2019a; Fowler et al., 2019b) accounts for the noteworthy enrichment of sulfur in the vent mineral deposits on the lake floor in the Deep Hole (Fig. 5C). $\mathrm{H}_{2} \mathrm{~S}$ addition to sediment derived iron can be expected to form pyrite and/or pyrrhotite as observed, the latter under more reducing conditions. Pyrite is a common alteration phase throughout YNP, and has been especially well described in the vapor-dominated region of the Y-11 drill hole (White et al., 1975). Rock derived starting iron, however, is difficult to identify within the reference core (YL17U05). For this reason hematite—stable in redox conditions of the Lake bottom water (Fowler et al., 2019c) —and magnetite—identified within the venting area (Fowler et al., 2019b) as well as a common lithological factor that can make up the detrital riverine sediment (Chafee et al., 2007) — are presumed to be the dominant iron minerals within this system. Additionally, as alteration progresses in the system iron remains relatively conservative with mass depletion, with the exception of YL17U02B and top sediments of YL17U02 and YL17U04 owing to pyrite mobility by venting flow displacement. 
$\underline{\mathrm{A}}$

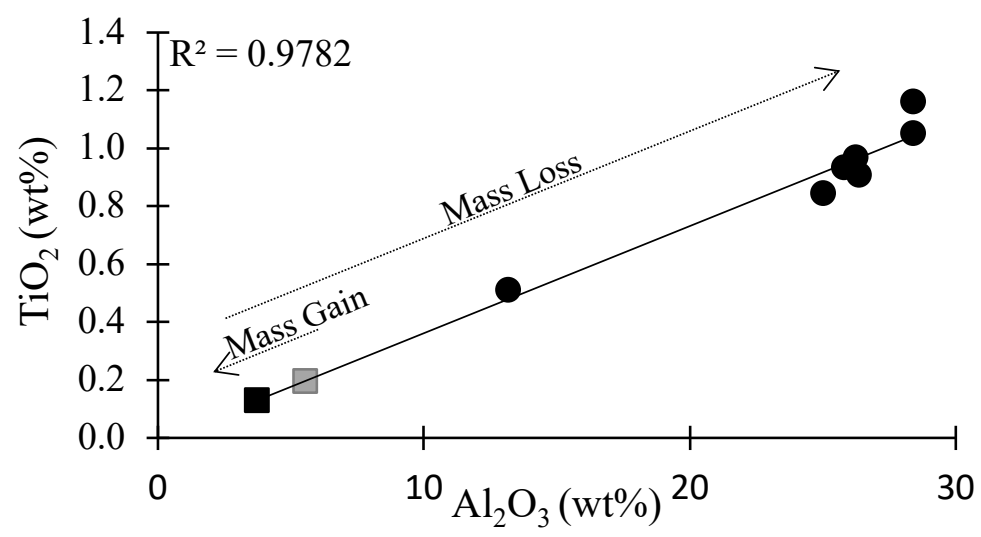

$\underline{B}$

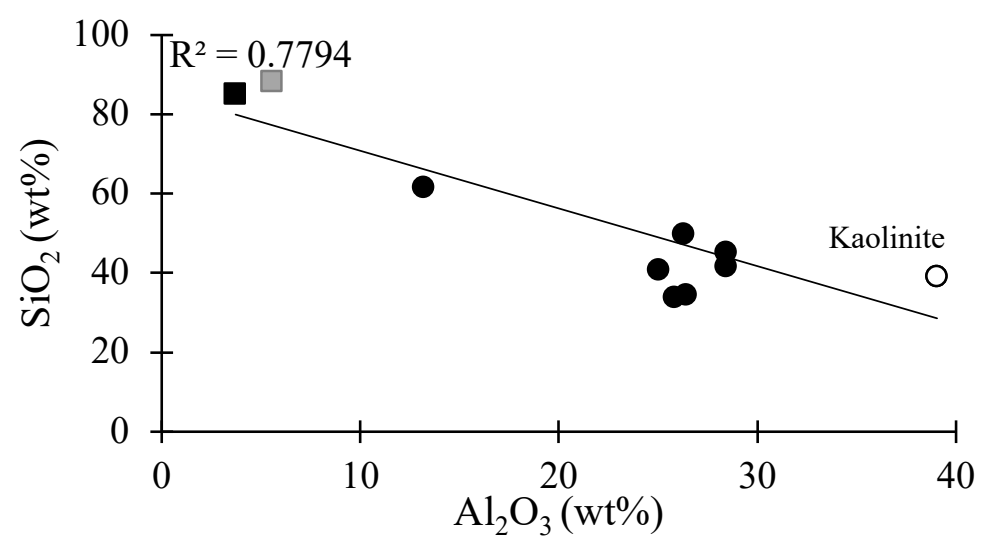

$\underline{\mathrm{C}}$

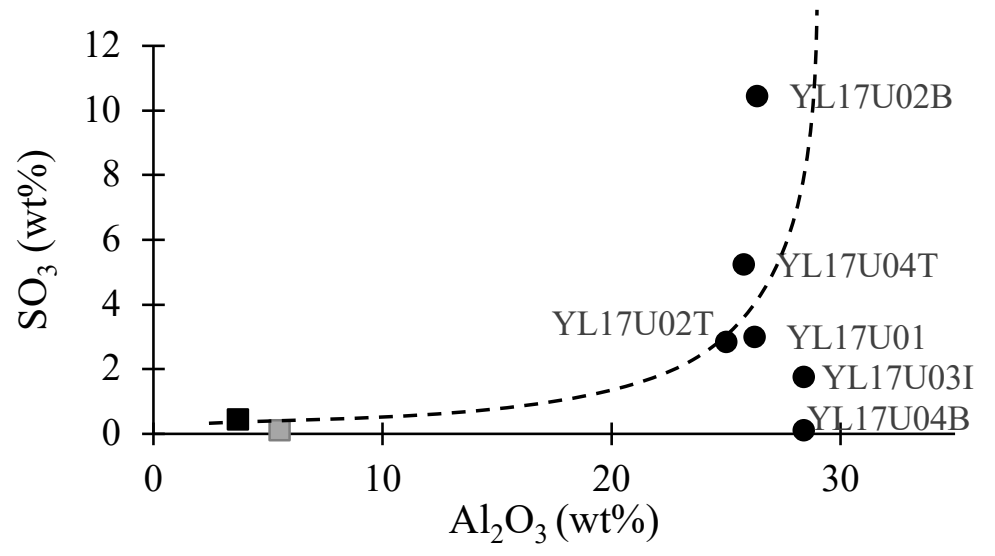

- Stevenson Island

- Unaltered Deep Lake Sediment (Morgan et al., 2009b)

$\square$ River Sediment Load (Chafee et al., 2007)

Figure 5. (A) $\mathrm{Al}_{2} \mathrm{O}_{3}$ and $\mathrm{TiO}_{2}$ concentrations display mass loss from fresh (diatomaceous) to altered (Stevenson Island) sediment. Attributing to the silica loss (B) necessary to form the dominate alteration product of kaolinite. Alteration of sediments may additionally be identified by sulfur enrichment $(C)$ of sediment attributing to pyrite and pyrrhotite formation from detrital iron minerals. 


\subsection{Hydrogen Isotopes}

$\mathrm{D} / \mathrm{H}$ isotopic composition of sediment samples range from -139 to $-157 \%$; up to $35 \%$ lighter than that measured for fluid samples and up to $10 \%$ heavier depending on specific conditions of hydrothermal alteration processes (Table 3). The isotopically light D/H values are consistent with formation of hydrous alteration (Sheppard and Gilg 1996). Sample YL17U02M, where kaolinite is the only hydrous alteration mineral, indicates $\delta \mathrm{D}$ of $-155 \%$, underscoring the magnitude of isotopic fractionation that is possible during acid metasomatism of the lakebed sediments. Mixed alteration assemblages, such as, kaolinite-boehmite, indicate $\delta \mathrm{D}$ values of -152 to $-157 \%$. Kaolinite-smectite assemblages, however, are isotopically heavy $(-139$ to $-141 \%)(\mathrm{D} / \mathrm{H})$ in proposition of the relative abundances of the two minerals, as smectite $\mathrm{D} / \mathrm{H}$ values are isotopically heavy in relation to kaolinite (Sheppard and Gilg, 1996).

Table 3.Deuterium/Hydrogen isotope values of SI Deep Hole fluid and sediment.

\begin{tabular}{cccccc}
\hline Sample & Vent Name & Type & Measure Temperature & dD \\
\cline { 5 - 6 } YL16F01 & $08152016-1$ & Fluid & 63 & -124 \\
YL16F02 & $08152016-1$ & Fluid & 86 & -124 \\
YL16F03 & $08152016-1$ & Fluid & 112 & -125 \\
YL16F05 & $08162016-1$ & Fluid & 94 & -122 \\
YL16F07 & $08162016-2$ & Fluid & 140 & -124 \\
YL16F06 & $08162016-3$ & Fluid & 101 & -124 \\
YL16F08 & $08172016-1$ & Fluid & 126 & -126 \\
YL16F09 & $08172016-2$ & Fluid & 92 & -123 \\
YL16F10 & $08172016-3$ & Fluid & 97 & -125 \\
YL16F11 & Vent 1 & Fluid & 130 & -124 \\
YL16F12 & Vent 1 & Fluid & 112 & -125 \\
YL16F13 & Vent 1 & Fluid & 83 & -124 \\
YL16F14 & Vent 1 & Fluid & 149 & -125 \\
YL17F01 & Vent 1 & Fluid & 150 & -127 \\
YL17F02 & Vent 1 & Fluid & 146 & -126 \\
YL17F03 & Vent 2 & Fluid & 142 & -125 \\
YL17F08 & Vent 1 & Fluid & 128 & -125 \\
YL18F02 & Vent 1 & Fluid & 118 & -129 \\
YL18F03 & Vent 2 & Fluid & 66 & -125 \\
YL18F04 & Vent 1 & Fluid & 70 & -123 \\
YL17U01 & Vent 1 & Sediment & - & -155 \\
YL17U02T & Vent 1 & Sediment & - & -157 \\
YL17U02B & Vent 1 & Sediment & - & -152 \\
YL17INSERT & Vent 2 & Sediment & - & -139 \\
YL17U04T & Vent 2 & Sediment & - & -156 \\
YL17U04B & Vent2 & Sediment & - & -141
\end{tabular}

Fluid measured and previously recorded by Fowler et al., 2019c.

- Not Applicable 


\section{DISCUSSION}

\subsection{Fluid-Mineral Alteration: Sources and Processes of Hydrothermal Activity}

Yellowstone Lake bathymetry reveals the influence of significant seismic and volcanic processes, especially in the Northern area of the lake, with concomitant effects on hydrothermal alteration. For example, north-trending faults and fissures potentially provide effective pathways for more deeply circulating hydrothermal fluids to ascend to the lake floor, guided further by rhyolitic, glacial, and lacustrine units, where abundant hydrothermal features and deposits have been long been recognized (Christiansen, 2001; Morgan et al., 2003; Morgan et al., 2009). In the absence of hydrothermal alteration effects, however, lacustrine sediments in Yellowstone Lake contain abundant diatoms as well as aluminosilicate and oxide minerals, the latter derived from weathering reactions on land, surrounding the lake, and then transported to the lake floor by normal settling processes and often turbidity currents, initiated along the margins of the lake by seismic activity or other geological phenomena (Chaffee et al., 2007; Johnson et al., 2003; Morgan et al., 2003; Morgan and Shanks, 2005). Additionally, sedimentation by slump related redisposition of diatomaceous material from unstable regions of domal structures, presents yet another pathway for previously unaltered sediment to accumulate on the lake floor where hydrothermal activity may be more active (Johnson et al., 2003; Morgan et al., 2003; Morgan et al., 2009). Thus, prior to the onset of hydrothermal alteration, Yellowstone Lake sediments are best described as a mixtures of detritally sourced aluminosilicates, iron oxides, and a disproportionately large fraction of siliceous diatoms. Hydrothermal activity-long recognized in the SI Deep Hole-effectively transforms the detrital and biologically sourced sediments into minerals stable at elevated temperatures 
and pressures. Moreover, the compositional change induced by temperature and pressure effects, however, is enhanced greatly by the flux of hydrothermally sourced components through sedimentary precursors having inherently low permeability. The low permeability, in fact, is manifest by anastomosing networks of small mineralized cracks and fractures, but which is still sufficient to allow heat and mass transfer, especially considering the magnitude of the sustained heat source fueling SI Deep Hole vents. Accordingly, both conductive and advective heat transfer processes are involved. As emphasized throughout this report, a key element in the magnitude of hydrothermal alteration in SI Deep Hole vents is not just an effective circulation system, facilitating mass transfer, but it is the very nature of the physical and chemical character of the fluid itself that makes it so effective as an agent of compositional change. Here and elsewhere (Fowler et al., 2019a; Fowler et al., 2019b), the vapor-dominated character of the hydrothermal "fluid" has been emphasized. Importantly, the high enthalpy, low total dissolved solids, and noteworthy concentrations of $\mathrm{H}_{2} \mathrm{~S}$ and $\mathrm{CO}_{2}$, underscore the effectiveness of such a fluid to enhance mineral dissolution and precipitation processes, especially considering the inferred composition of the unaltered substrate through which the vapor dominated fluid passes prior to venting on the lake bottom. Reaction of hot vapors and their condensate-rich fluid and Yellowstone Lake water (Fowler et al., 2019a; Fowler et al., 2019b) with sediment dominated by inherently unstable components, especially diatomaceous silica, provides an unusually strong thermodynamic driving force for dissolution and volume change; where volume change provides a positive feedback mechanism enhancing further fluid/vapor infiltration and mineral dissolution. Accordingly, as reaction progresses with sufficiently high influx (high fluid/mineral 
substrate ratio), the silica-rich components of the protolithic (substrate) are particularly vulnerable to dissolution, as emphasized in earlier studies of sub-lacustrine hydrothermal alteration processes in Yellowstone Lake (Fowler et al., 2019a; Morgan et al., 2009;

Shanks et al., 2007).

\subsection{Phase Equilibria Constraints on Mass-Transfer Processes}

Phase equilibria in the $\mathrm{SiO}_{2}-\mathrm{H}_{2} \mathrm{O}$ system at temperatures and pressures broadly in keeping with conditions recognized for the SI Deep Hole (Fowler et al., 2019a), illustrates well the effect of temperature on the solubility of silica polymorphs, with relevance to the temporal evolution of the SI hydrothermal vent deposits (Fig. 6). Amorphous silica solubility (diatom proxy) increases sharply with increasing temperature

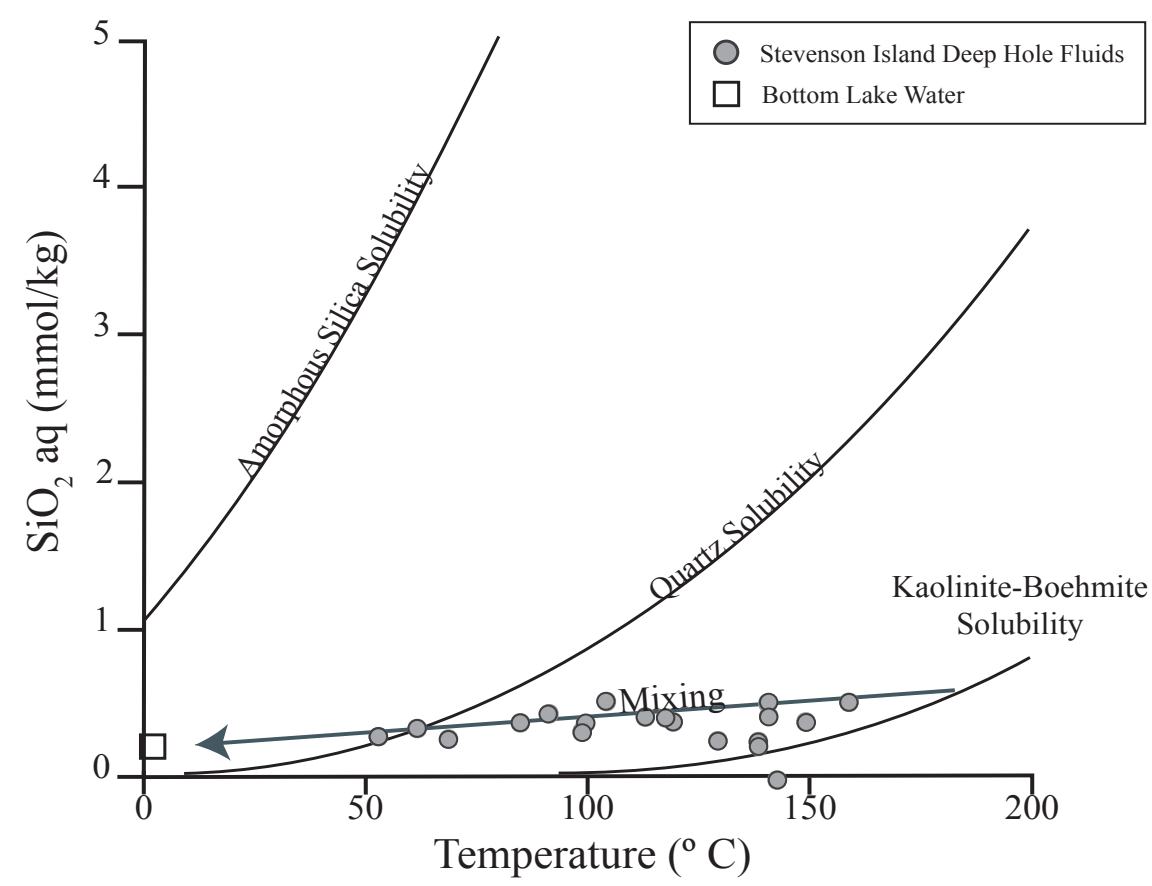

Figure 6. Stevenson Island vent fluid silica concentration and measured temperature relationship shows fluid mixing in trend with Bottom Lake Water. Kaolinite-boehmite equilibrium is approached around $180^{\circ} \mathrm{C}$. Measured fluid values are undersaturated with respect to amorphous silica at all temperatures and quartz at temperatures above $74^{\circ} \mathrm{C}$. 
to predicted values that are orders of magnitude greater than observed for the high temperature SI vent fluids (Fowler et al., 2019a; Fowler et al., 2019c), thus having the capacity to dissolve diatomaceous sediment present in the system as the fluid is undersaturation in respect to amorphous silica. Indeed, taken together, the SI vent fluids define a silica solubility trend consistent with kaolinite-boehmite over the full range of temperatures encountered, which in turn is mitigated by the degree of mixing between the vapor-bearing source fluid and lake water. Extrapolating this the highest temperature fluid samples $\left(174^{\circ} \mathrm{C}\right)$ actually intersects with the kaolinite-boehmite phase boundary (Fig. 6). Thus, inferences drawn from these data strongly suggest the systematic dissolution of amorphous silica and its stepwise replacement, first by quartz and then, ultimately kaolinite. These data, of course, provide little or no constraint on the time necessary for this sequence to occur from beginning to end, but the implications for reaction progress in qualitative terms are clear.

The push core samples and bulk composition of SI Deep Hole vent mineralization is generally consistent with predictions inferred from phase equilibria constraints depicted in Fig. 6. It is important to emphasize that the composition and abundance silicate minerals in push cores from active (YL17U01, YL17U03I) and from regions slightly off-set from active vent sites (YL17U02, YL17U04), is broadly similar, but not identical. Although kaolinite is indeed the dominant mineral (Table 1), in keeping with the silica depleted nature of the vapor dominated fluids and the noteworthy fluid flux recharging SI vents, quartz and even occasional diatoms can still be detected owing to the heterogeneous processes intrinsic to lake floor sediments, hydrothermal alteration notwithstanding. Quartz, for example, can be produced in place in the cores, especially 
during relatively early stages of alteration, where diatom dissolution is incomplete. During this stage of alteration, pore fluids in the cores, cut off from more active fluid flow channels, could achieve metastable concentrations of dissolved silica higher than that predicted for kaolinite-boehmite-fluid equilibria, enhancing quartz stability and maintaining the presence of this mineral in spite of the near continuous influx of silica starved fluids. As all cores have identifiable amounts of quartz coexisting with kaolinite, minus YL17U02M, this interpretation is consistent with our results.

\subsection{Reaction Path Modelling}

The influx of $\mathrm{CO}_{2(\mathrm{~g})}$ and $\mathrm{H}_{2} \mathrm{~S}_{(\mathrm{g})}$ bearing vapor on dissolution and precipitation processes of an assemblage of minerals, inferred to represent the unaltered lacustrine sedimentary components, can still be instructive, both qualitatively and quantitatively. Thus, Geochemist's Workbench (Bethke and Yeakel, 2012) version 12.0.5, with a $150^{\circ} \mathrm{C}$, steam saturation pressure database, created using the DBCreate (Kong et al., 2013) software package, was employed for speciation calculations, solubility and reactive transport models. The Drummond (1981) formulation was used to calculate activity coefficients of $\mathrm{CO}_{2}(\mathrm{aq})$ in solution, and internally consistent thermodynamic data presented by Tutolo et al. (2014) was employed for Al-bearing minerals and aqueous species, quartz, and $\mathrm{H}_{4} \mathrm{SiO}_{4}(\mathrm{aq})$. Silicic acid ionization constants and $\mathrm{SiO}_{2}(\mathrm{am})$ thermodynamic data came from Busey and Mesmer (1977) and Gunnarsson and Arnorsson (2000), respectively. Data for the remaining aqueous species and minerals were generally consistent with the standard SUPCRT92 (Johnson et al., 1992) dataset. In calculations of saturation indices for the single-pass experiments, chloride concentrations 
(which were not measured) were set equal to analytical Na concentrations. Saturation index $(\Omega)$ was calculated according to:

$$
\Omega=\log \left(\frac{Q}{K}\right)
$$

where $\mathrm{Q}$ and $\mathrm{K}$ are the ion activity product and equilibrium constant, respectively. The chemical affinity, $\Delta \mathrm{G}_{\mathrm{r}}$ was calculated according to:

$$
\Delta G_{r}=-R T_{K} \ln (\Omega)
$$

where $\mathrm{R}$ is the ideal gas constant $(8.314 \mathrm{~kJ} / \mathrm{mol} / \mathrm{K})$ and $\mathrm{T}_{\mathrm{K}}$ is the temperature in Kelvin.

Results of multicomponent reaction path models depicting hydrothermal alteration of sub-lacustrine sediments inferred to exist in the Deep Hole region, east of Stevenson Island (Table 4), indicate large scale changes in both chemical composition and mineralogy. For example, at an assumed reaction temperature of $150^{\circ} \mathrm{C}$, incremental addition of the $\mathrm{H}_{2} \mathrm{~S}$ and $\mathrm{CO}_{2}$ bearing vapor/condensate to the diatomaceous sediment, replaces $\mathrm{Fe}$, and, $\mathrm{Al}$ and $\mathrm{Si}$, components, with an alteration assemblage of pyrite and kaolinite, respectively, with boehmite predicted to form with further increase in reaction progress. Incipient reaction, on the other hand, yields expandable clay minerals, such as beidellite, which ultimately are also replaced by kaolinite (Fig.7A). The relative abundance of product minerals, however, are a simple function of mass balance constraints imposed by the protolith composition, with greater amounts of Al bearing components, producing greater amounts of kaolinite. Clearly, diatomaceous silica, which can be approximated thermodynamically by amorphous silica, and is undoubtedly a dominant component of the fresh lacustrine sediment (Table 4), is predicted to dissolve completely, first replaced by quartz, and then ultimately kaolinite, giving rise to a series of steady state conditions or "steps" in dissolved silica concentrations with reaction 

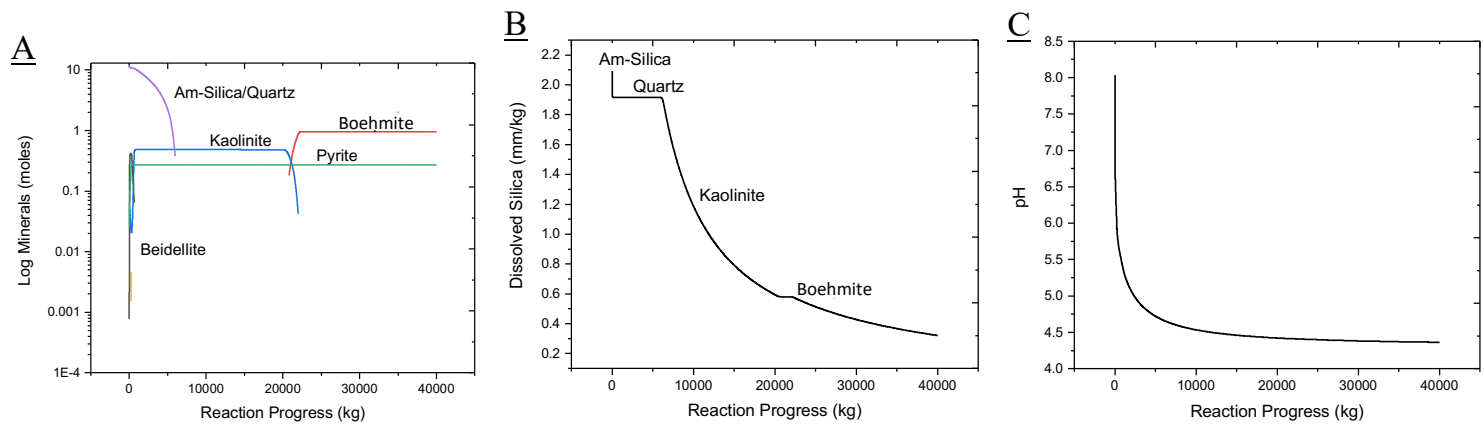

Figure 7. Predicted change in mineral and fluid composition at $150^{\circ} \mathrm{C}$ in response to reaction of inferred lacustrine sediments in the Yellowstone Lake Deep Hole (Stevenson Island) with vapor dominated hydrothermal vent fluids (Fowler et al. 2019a, 2019b). The $\mathrm{H}_{2} \mathrm{~S}(\mathrm{~g})$ and $\mathrm{CO}_{2}(\mathrm{~g})$ bearing vapor enhances large scale recrystallization of sediment components. Pyrite, kaolinite and boehmite increase with increasing reaction progress, while amorphous silica (diatom-bearing sediment) first transforms to quartz and then is undergoes near quantitative removal from the sedimentary system (A). Predicted changes in dissolved silica $(B)$ and $\mathrm{pH}(\mathrm{C})$ with reaction progress. The composition of unaltered lacustrine sediment is as follows: $62 \%$ diatoms, $6 \%$ albite, $22 \%$ smectite, $7 \%$ illite and $3 \%$ magnetite (see text).

progress (Fig. 7B). Even so, model results are definitive in the extent to which silica bearing components of the inferred sedimentary protolith are rendered unstable during hydrothermal alteration, owing both to reaction temperature and the continuous influx of vapor and condensate, which initially can be expected to be devoid of dissolved silica (Fournier and Rowe, 1977), enhancing dissolution of coexisting silica-bearing minerals, especially associated with diatomaceous assemblages. Although $\mathrm{pH}$ lowering reactions associated with the influx and hydrolysis of $\mathrm{CO}_{2(\mathrm{~g})}$ from vapor sources, has little effect on amorphous silica solubility, this is not the case for aluminosilicates minerals thought to characterize unaltered sub-lacustrine sediments (Table 4). It is noteworthy, that the decidedly low pH predicted from phase equilibria constraints (Fig. 7C), agrees well with in-situ values actually measured at the SI vents using solid state electrochemical sensors (Tan et al., 2017). This may be coincidental, but could also provide confirmatory evidence of the extent of reaction (Fig. 7) for the vapor dominated SI hydrothermal system in Yellowstone Lake. 
Table 4. Unaltered sediment composition

\begin{tabular}{|c|c|c|}
\hline Mineral & Compositional Mass \% & Comments \\
\hline Amorphous Silica & 62 & $\begin{array}{l}\text { Amorphous silica is assumed to be dominate silica phase as stated in Shanks et al., } \\
2007 \text {. Mass balance calculations determine that there is a } 33 \% \text { silica mass gain from } \\
\text { the precursor River Load sediment (Chafee et al., 2007). Therefore, amorphous silica } \\
\text { percentage is calculated using this equivalent mass gain percentage applied to silica } \\
\text { molar composition of unaltered lake sediment, neglecting quartz, as determined in } \\
\text { Morgan et al., 2009b. }\end{array}$ \\
\hline Smectite & 22 & $\begin{array}{l}\text { Smectite percentage is determined by assuming all Ca mols of unaltered lake } \\
\text { sediment of Morgan et al., } 2009 \mathrm{~b}\end{array}$ \\
\hline Illite & 7 & Illite percentage is determined by assuming all $\mathrm{K}$ mols of Morgan et al., 2009b \\
\hline Albite & 6 & Albite percentage is determined by assuming all Na mols of Morgan et al., 2009b \\
\hline Magnetite & 3 & $\begin{array}{l}\text { Magnetite is assumed iron phase as it is a common lithological factor that can make } \\
\text { up detrital riverine sediment (Chafee et al., 2007). Thus, magnetite percentage is } \\
\text { determined by assuming all of } \mathrm{Fe} \text { mols of Morgan et al., 2009b }\end{array}$ \\
\hline
\end{tabular}

Minerals such as albite and K-feldspar - as detected in shallow and unaltered sediment of YL17U05, YL17U02T, and YL17U01 — are increasingly soluble (undersaturated) in the moderate to distinctly acid fluids of the type predicted from model results (Fig. 7C). Thus, the transformation of these minerals to kaolinite and ultimately boehmite, is not surprising. Model results from reaction path calculations suggest volume loss of approximately $80 \%$, relative to the inferred mass and volume of the starting mineral assemblage, mostly due to the dissolution of intrinsically unstable diatomaceous (amorphous) silica. Model predictions are also broadly in keeping with chemical—model progresses from $5 \mathrm{wt} . \% \mathrm{Al}_{2} \mathrm{O}_{3}$ to $30 \mathrm{wt} . \%$ consistent with bulk cores samples that may achieve up to 29 wt. $\% \mathrm{Al}_{2} \mathrm{O}_{3}$-and mineralogical data from push core samples obtained at or near hydrothermal up-flow zones in the SI Deep Hole, providing a good first approximation of quantitative controls on mass transfer reactions occurring on the floor of Yellowstone Lake. For example, smectite observed in some of these cores (YL17U03I, YL17U04B) can best be interpreted as a product of incipient stages of alteration when 
reaction progress was limited

such that sufficient silica existed

to "buffer" silica at or above

quartz saturation. This would be

especially true at relatively low

pH values (Fig. 7, 8). Smectite

and kaolinite-boehmite alteration

assemblages cannot coexist at

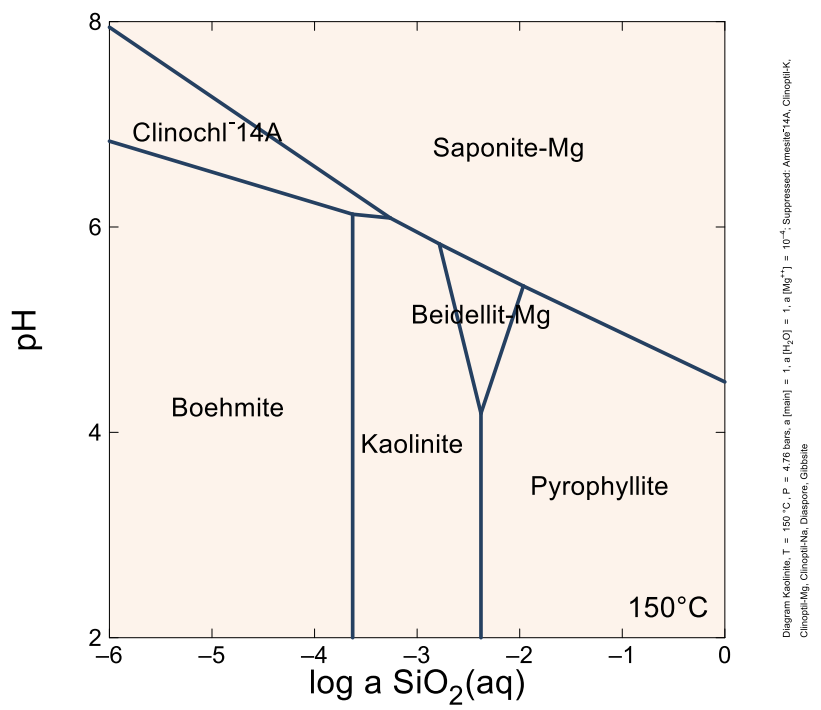

equilibrium and their presence in

Figure 8. Phase diagram in the $\mathrm{MgO}-\mathrm{Al}_{2} \mathrm{O}_{3}-\mathrm{SiO}_{2}-\mathrm{H}_{2} \mathrm{O}-\mathrm{HCl}$ system at $150^{\circ} \mathrm{C}$ and steam saturation pressure. Data indicate the role of $\mathrm{pH}$ and dissolved silica in accounting for the relative stability smectite and kaolinite/boehmite bearing assemblage. Assuming full equilibrium, smectite (beidellite)

different stages of alteration with can form only during incipient stages of reaction which the opposite is true for kaolinite-boehmite.

reaction progress and local

metastability.

\subsection{Kinetic Considerations}

The existence of relatively silica-rich alteration phases, such as smectite and quartz in the push cores from hydrothermally active vents at Stevenson Island place important constraints on the ingress of vapor and its condensate into the near surface reaction zone undergoing alteration and mineralization. The abundance of diatomaceous (amorphous) silica in the fresh or unaltered lacustrine sediments in Yellowstone Lake has long been inferred as source of silica for hydrothermal fluid venting into the Lake (Shanks et al., 2007), but also for the observed mineralization. Reaction path calculation (Fig. 7) suggest that this is the case; that is, as increasingly greater amounts of source fluid flow through the system, smectite and quartz would become less abundant, being 
replaced by kaolinite and ultimately boehmite. Reaction path models of this sort, however, provide no information on the time for transformation of one mineral to another, with implications for time series changes in the concentrations of coexisting dissolved species. Using a combination of experimental and theoretical data, Rimstidt and Barnes (1980) developed a kinetic rate law for silica polymorphs, including, quartz and amorphous silica in terms temperature, pressure, and mineral surface area relative to the mass of fluid, or $\mathrm{A} / \mathrm{M}$ (area/fluid mass ratio), as follows:

$$
\left(\frac{\partial_{\mathrm{H} 4 \mathrm{SiO} 4}}{\partial_{t}}\right)_{P, T, m}=\left(\frac{A}{M}\right)\left(\gamma_{\mathrm{H} 4 \mathrm{SiO} 4}\right)\left(k_{+} a_{\mathrm{SiO} 2} a_{\mathrm{H} 2 \mathrm{O}}^{2}\right)-k_{-} a_{\mathrm{H} 4 \mathrm{SiO} 4}
$$

These data indicate that at a temperature of $150{ }^{\circ} \mathrm{C}$ and initially high $\mathrm{A} / \mathrm{M}$ values, typical of an incipiently closed system condition, reaction times on the order of weeks or less would all that would be necessary for full equilibrium for silica-water reactions. Accordingly, the transformation of diatomaceous silica to quartz would be expected to occur during this time. In open geochemical systems, however, the continuous influx of fluid can be expected to decrease $\mathrm{A} / \mathrm{M}$, with corresponding decreases in dissolved silica concentrations as the inflowing fluid continuously dilutes silica in solution that is released first from amorphous silica and then quartz. We can illustrate this using a simple $1 \mathrm{D}$ reactive flow model at $150^{\circ} \mathrm{C}$ in which $1 \mathrm{~kg}$ of amorphous silica coexisting with pore fluid ( $\sim 50 \%$ porosity) is incrementally reacted with a silica poor source fluid at a fixed rate, broadly consistent with vapor/condensate reaction with diatomaceous sediment in the SI Deep Hole. The physical and chemical constraints imposed on the model are included in Table 5. Here we have adopted amorphous silica surface area of $\sim 10 \mathrm{~m}^{2} / \mathrm{g}$ in keeping with actual measurements made of diatom from acid dissolution studies (Zang 
Table 5. Dissolution Model Constraints

\begin{tabular}{lll}
\hline Constrains & Parameter & Values \\
\hline \hline Basis & Time & $10 \mathrm{yr}$ \\
& Length & $100 \mathrm{~cm}, 10$ nodes \\
& Flow velocity & $0.01 \mathrm{~cm} / \mathrm{s}=0.001 \mathrm{~kg} / \mathrm{s}$ \\
& Cross Sectional Area & $10 \mathrm{~cm} \mathrm{x} 10 \mathrm{~cm}$ \\
\hline Node & Volume & $1000 \mathrm{~cm}^{3}$ \\
& Porosity & 0.5173 \\
& Mineral & $482.7 \mathrm{~cm}^{3}$ \\
& Amorphous Silica Density & $2.07 \mathrm{~g} / \mathrm{cm}^{3}$ \\
\hline Initial & H2O & $1 \mathrm{~kg}$ \\
& Amorphous Silica $=\mathrm{SiO} 2_{(\text {aq }}$ & $1000 \mathrm{free} \mathrm{g}$ \\
& Temperature & $150{ }^{\circ} \mathrm{C} \mathrm{constant}$ \\
\hline Amorphous Silica Reactant & Surface area & $100000 \mathrm{~cm}^{2} / \mathrm{g}$ \\
& Rate Constant & $1.4910^{13} \mathrm{~cm}^{2} / \mathrm{g}$ \\
\hline
\end{tabular}

Model Illustration:

Time $=10$ year
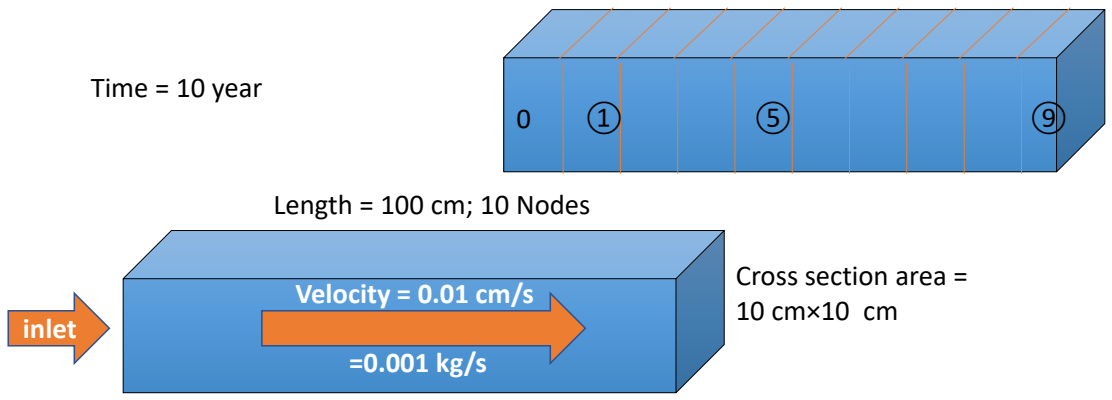

et al., 2011). Importantly, we have restricted the chemical system to include only $\mathrm{SiO}_{2}-$ $\mathrm{H}_{2} \mathrm{O}$, so as to avoid uncertainties in reaction rates and interfacial surface areas of compositionally more complex, but less well constrained minerals in multi-component assemblages, more typical, however, of natural systems. Thus, the purpose of this exercise, is to provide a preliminary estimate of dissolution rate of silica polymorphs in a compositionally limited and simplified flow system at elevated temperature and pressure. That diatomaceous silica is a dominant component of the unaltered sub-lacustrine sediment in Yellowstone Lake, enhances the value of the model, compositional restrictions notwithstanding. 
Ingress of the hot $\left(150^{\circ} \mathrm{C}\right)$ source fluid containing negligible dissolved silica into the amorphous silica bearing core at the assumed flow rate of $0.001 \mathrm{~kg} / \mathrm{yr}$., reveals undersaturation with respect to quartz and certainly amorphous silica and corresponding low dissolved silica concentrations (Fig. 9A). Thus, incipient reaction with both quartz and amorphous silica causes dissolution and corresponding increase in porosity (Fig. 9A, B), while simulated conditions downstream from the reaction front remain unchanged in terms of quartz saturation and porosity (quartz solubility at $150^{\circ} \mathrm{C}$ and steam saturation). Simulated year 2 reaction results in further penetration and mineral dissolution (Fig. 9C, D). After three years of reaction (Fig 10), only the final portion of the core (node 9) still contains quartz, with complete dissolution predicted for all times thereafter. Although the reactive transport model is limited in compositional variability and fluid flow rate, as well as, mineral (amorphous silica surface area), it still provides useful insight on the likely
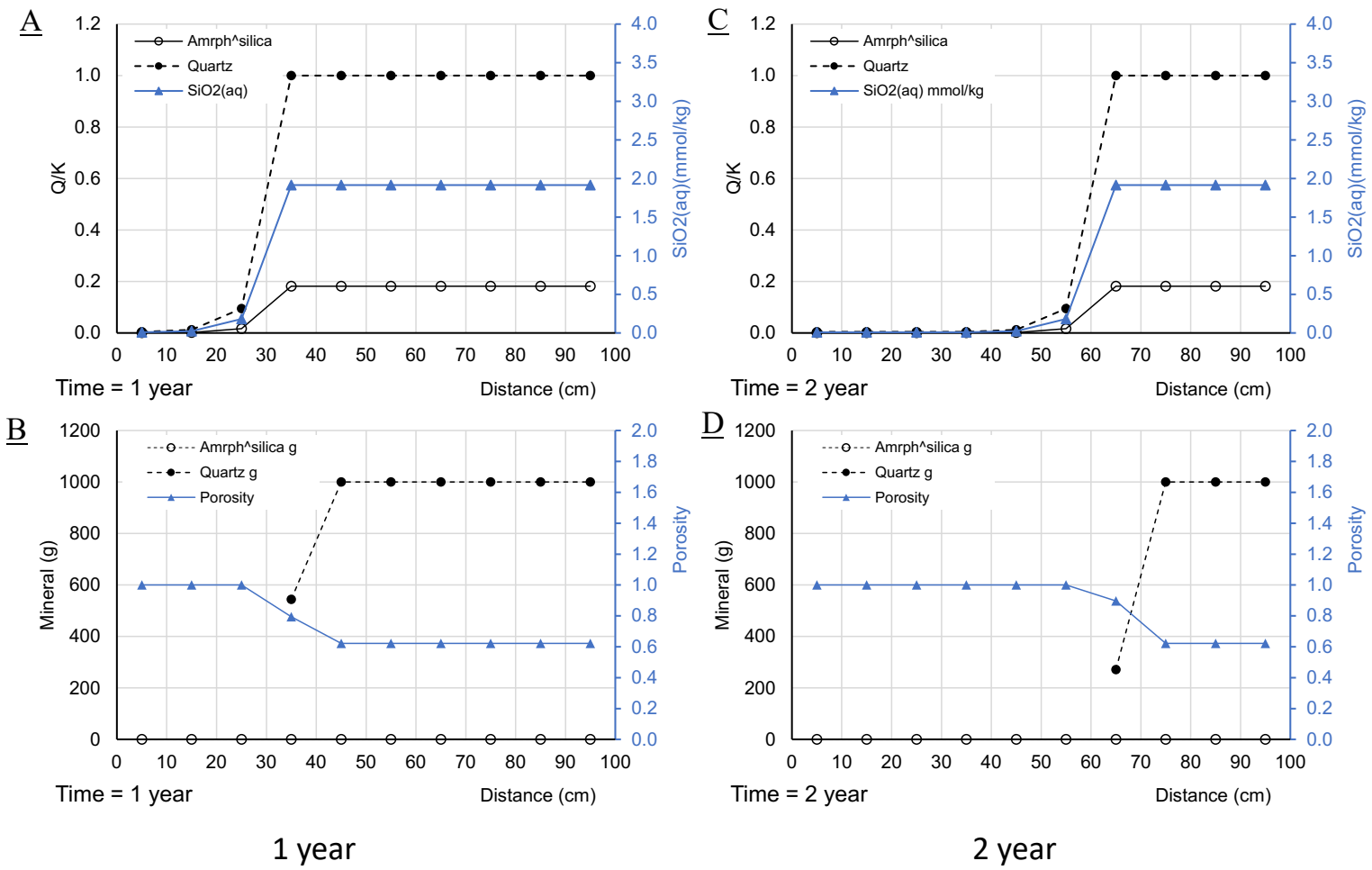

Figure 9. ID Reactive transport modeling step results 
time necessary for complete dissolution of amorphous silica and quartz in a hydrothermal up-flow zone. Increases in the fluid flow rate from that used here, would result in more rapid break-through times, while the opposite would be true for lower rates of fluid flow. These data provide some sense of the time necessary for the downward excavation of the lake floor beneath a hydrothermal up-flow zone, such as observed throughout the hydrothermal active Deep Hole region, off-shore of Stevenson Island (Shanks et al., 2007). Moreover, the predicted migration of quartz from one region of the hydrothermal up-flow zone to another has implications for the stability of other minerals, especially smectite and kaolinite, when high and moderate dissolved silica concentrations, respectively are available, and boehmite, when that is not the case.

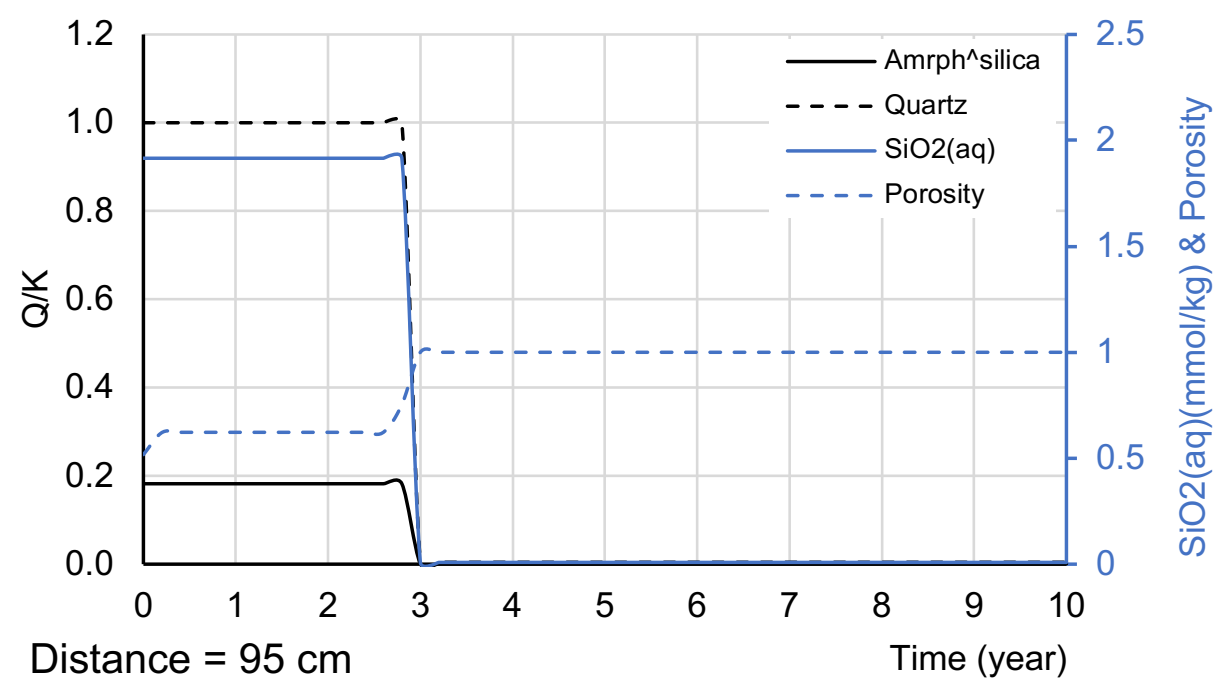

Figure 10. 1D Reactive Transport Modelling Results

The $1 \mathrm{D}$ reactive transport model confirms that amorphous silica/quartz rate of dissolution would be a complex function of a wide range physical factors unique to this chemical system, with implications for challenges when applied to compositionally more complex chemical systems. Other such studies, however, have underscored as well the 
role of catalytic or inhibitory agents- enhancing or inhibiting change- on rates of reaction between minerals and fluids. We have already commented on the low permeability of the core sediments that potentially isolates unstable minerals from reaction to more stable phases, slowing transformation to a more stable phase. Moreover, the three dimensional geometry of mineral surfaces and the possible, if not likely existence of surface coatings , so-called "effective surface area" (Lasaga, 1995) plays a critical role in reaction rate modeling. Although quantitatively important it is difficult to apply this to dynamical hydrothermal systems, such as at Deep Hole SI vents, particularly, because of the vagaries imposed by the anastomosing networks of micro-cracks separating minerals and fluids in space and time. On a finer scale, mineral surface heterogeneity are likely even more important. A particularly good example of this, with implications for the rate of diatom (amorphous silica) reactivity can be envisaged by careful analysis of the surface

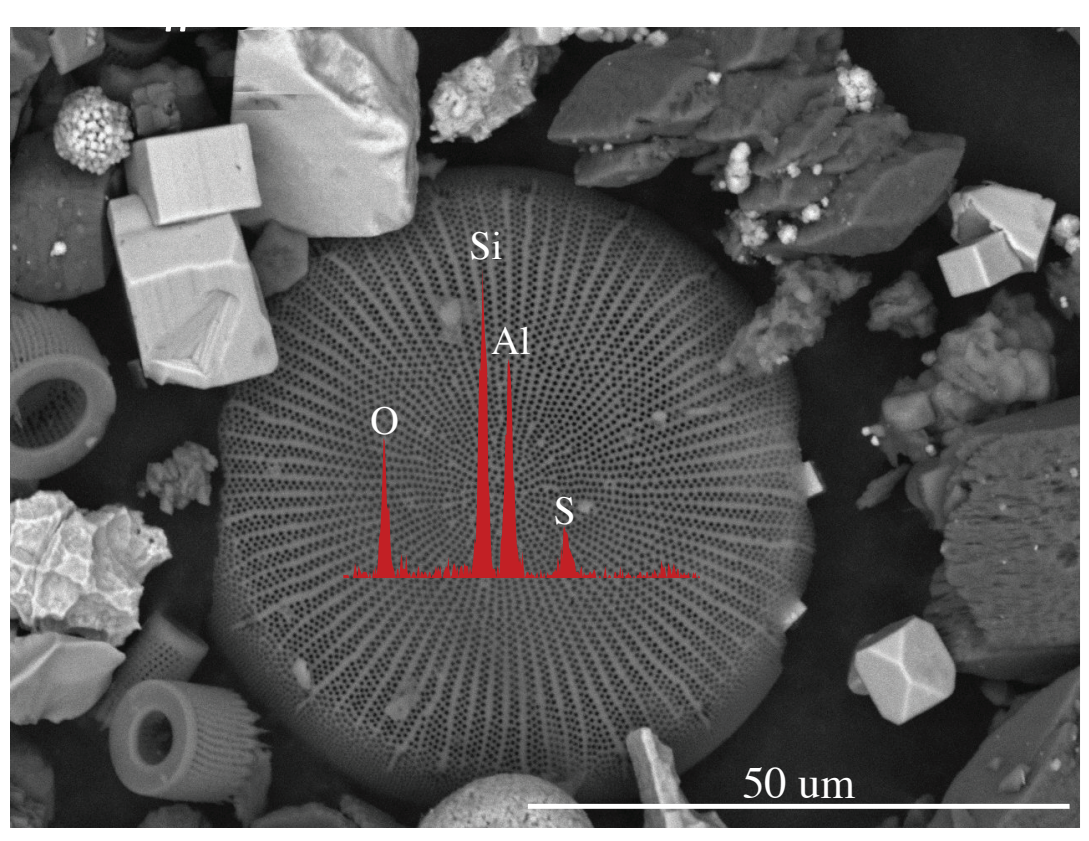

Figure 11. Diatom enriched in aluminum identified within the venting area, YL17U02. The surface coating likely inhibits rates of reaction and formation of more stable phases (see text). chemistry of a diatom microfossil from a push core, which from many other measures, such as the relative abundance of kaolinite, indicates high degrees of reaction progress. The articulation of the diatom suggests insignificant transformation to an 
inherently more stable mineral (i.e., kaolinite). Examination of the diatom, by energy dispersive X-ray analysis, however, reveals the structurally unseen presence of an aluminum oxide surface coating (Fig. 11). Thus, with the noteworthy existence of surface coatings and variability of time dependent changes in fluid flow paths, application of fully coupled reactive transport modeling may underestimate the true time for reactions in the $\mathrm{SiO}_{2}-\mathrm{H} 2 \mathrm{O}$ system (see above). Whether or not this is also the case for more complex chemical systems will have to be established independently using available experimental and theoretical data and from careful analysis of the surface chemistry of alteration minerals separated from vent deposits. .

\subsection{Acid Metasomatism and Redox Constraints}

The continuous influx of vapor-bearing gas components $\left(\mathrm{CO}_{2(\mathrm{~g})}, \mathrm{H}_{2} \mathrm{~S}_{(\mathrm{g})}\right)$ is clearly important for $\mathrm{pH}$ and redox regulation as expressed by the in-situ chemical data (Tan et al., 2017), but also, relevant to the chemical and mineralogical composition of the substrate through which the vapor/condensate pass, prior to mixing with lake water and venting on the lake floor. This is perhaps best illustrated by the previously described push core data. Indeed, these cores provide an insightful archive of mineralogical and chemical change for the sub-lacustrine Yellowstone Lake vent system at Stevenson Island. The cryptically layered core tops for core locations off-set from sites of active venting (YL17U02T, YL17U04T), reveals thermal alteration of diatomaceous sediment likely by conductive heat transfer from below. As elsewhere, the relatively impermeable nature of the lacustrine sediment accumulated by "normal" depositional processes, serves as an effective heat trapping mechanism for the underlying vapor-driven hydrothermal system. Advective heat and mass transport deeper within the core results in significant 


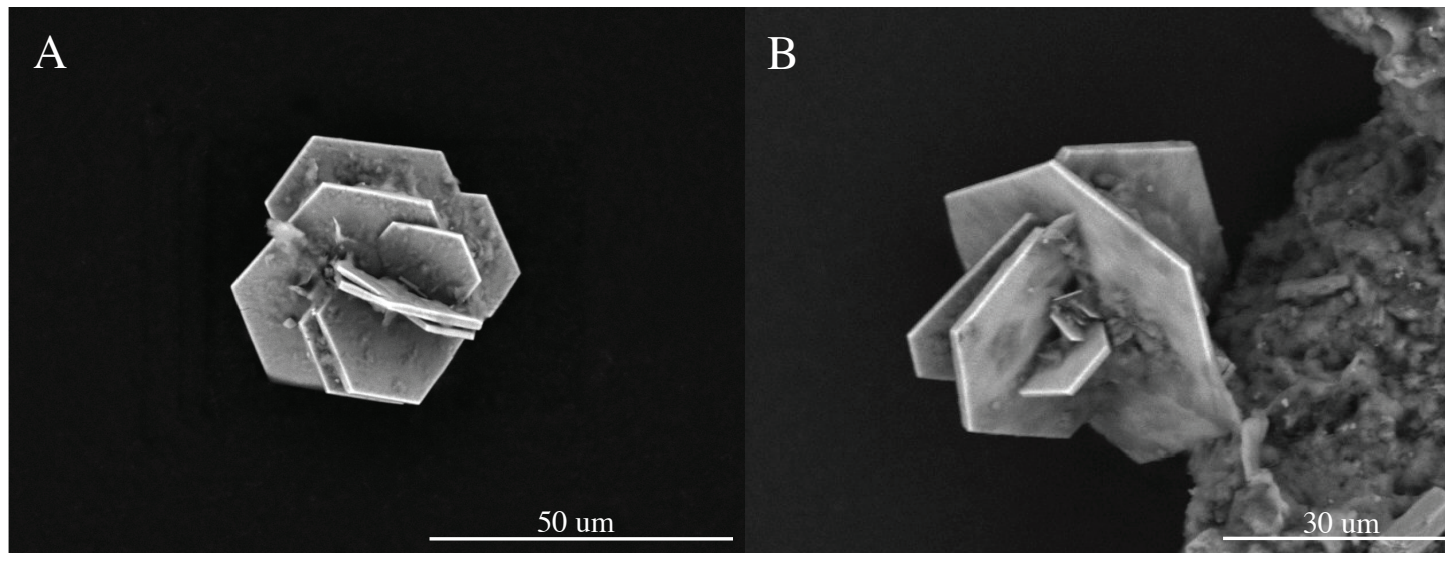

Figure 12. Pyrrhotite identified in Vent 1 sediment YL17U03I

mineralogical alteration and volume change. Mineral dissolution and precipitation in response to acid metasomatic $\left(\mathrm{CO}_{2(\mathrm{~g})}\right)$ effects and redox change $\left(\mathrm{H}_{2} \mathrm{~S}_{(\mathrm{g})}\right)$ gives rise to brecciated appearance, with well-developed color changes indicative of local redox and chemical gradients (Fig. 4). The existence of abundant pyrrhotite (Fig. 12) and more commonly pyrite with diverse crystallographic habits and sulfur isotopic values $\left(\delta \mathrm{S}^{34}=\right.$ 0.5\% to 5.3\%o) (Fowler et al., 2019b), provides evidence of the extent of redox heterogeneity and disequilibria that exists on a fine scale.

The generally constant redox conditions observed in vent fluid samples (Fowler et al., 2019a) and from electrochemical sensor data (Tan et al., 2017), however, are likely controlled by the influx of $\mathrm{H}_{2} \mathrm{~S}_{(\mathrm{g})}$, which upon mixing with sulfate-bearing Lake water (Fowler et al., 2019a), achieves a mildly reducing steady state redox condition (Fig. 13). Numerous studies of paired redox couples in groundwater and low to moderate temperature hydrothermal systems have long demonstrated a lack of internal equilibrium. This is indicated by noteworthy inconsistency of redox values predicted for individual redox couples as well as overall disagreement between predicted and measured redox intensity (Grenthe et al., 1992; Stefansson et al., 2005; Stumm and Morgan, 1996). In a 


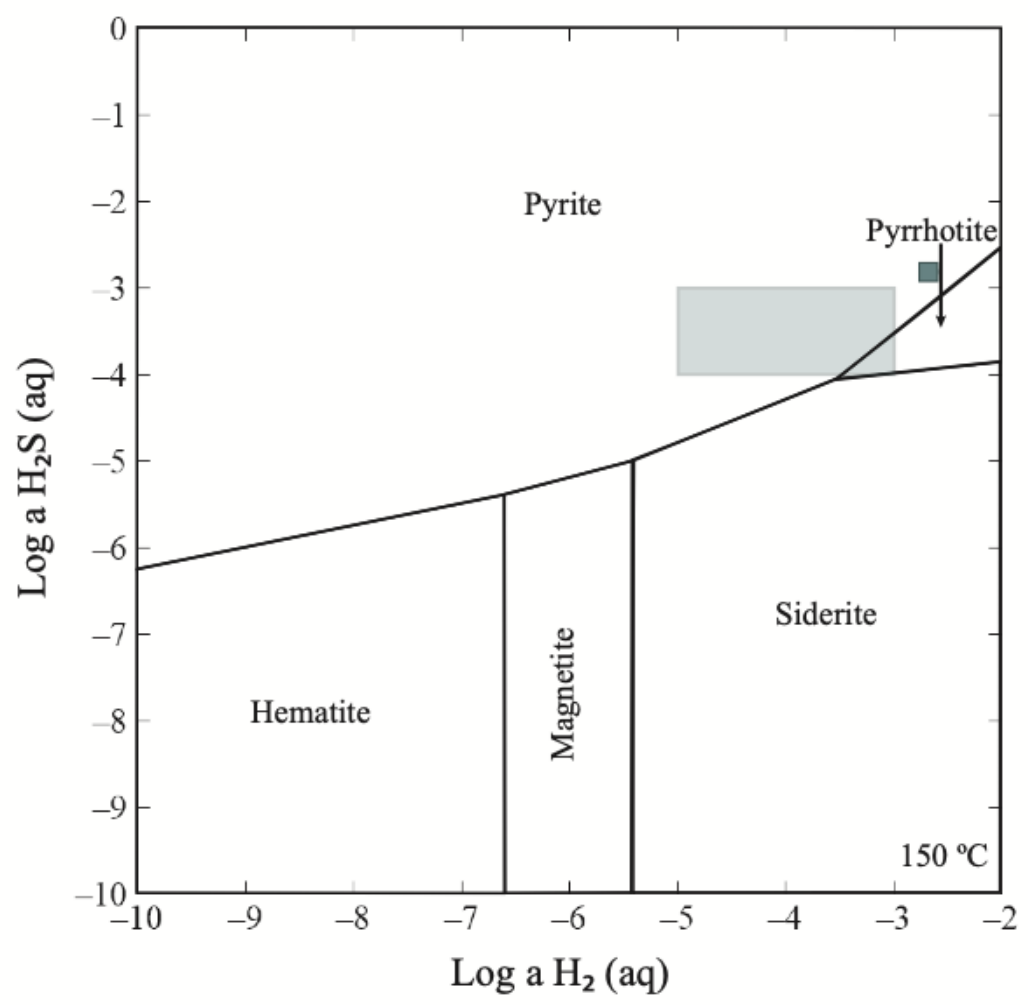

Figure 13. Reduction-Oxidation reactions of iron minerals within Stevenson Island Vent system. Constrains of fluid dissolved gas concentration within Vent 1 (light blue square) suggest redox reactions between pyrrhotite and pyrite. Dark blue square represents detected fluid range of dissolved gas concentration within Vent 2. Vent 2 is well within pyrite stability. Fluid values used are reported in Fowler et al., 2019c. These data are also broadly consistent with in-situ redox measurements from numerous SI vents (Tan et al., 2018).

more qualitative sense, however, the putative redox condition provides support for a fluid (vapor) dominated hydrothermal vent environment, where the influx of $\mathrm{H}_{2} \mathrm{~S}_{(\mathrm{g})}$ occurs at a sufficiently high rate so as to preclude more oxidizing conditions imposed by infiltration of lake water (sulfate bearing) or development more reducing conditions, possibly mediated by the breakdown of diatomaceous organic matter.

Moreover, the conversion of previously unreacted (detritally sourced) minerals and diatomaceous silica to kaolinite and boehmite (Fowler et al., 2019a; Fowler et al., 2019c), is a classic acid alteration sequence that provides evidence of the relatively large 
influx of vapor-sourced fluid that occurs over time throughout the core. These fluids ultimately locate more permeable zones and escape to the Lake floor. Many of these same patterns of alteration and mass transfer are well illustrated in subaerial fumarole vent systems throughout YNP, where bleached ground contains pyrite, native sulfur and clay minerals, especially kaolinite (Fournier, 1989; Hurwitz and Lowenstern, 2014).

\subsection{Isotope Constrains}

$\mathrm{D} / \mathrm{H}$ isotopic data for vent minerals can constrain conditions of hydrothermal alteration provided sufficiently accurate mineral-fluid fractionation data are available (Bowers and Taylor, 1985). The interpretation of kaolinite $\mathrm{D} / \mathrm{H}$ fractionation is based largely on experimental and field data from Sheppard and Gilg (1996), as follows:

$$
\begin{gathered}
10^{3} \ln \propto_{k a O-H 2 O}=-2.2 \times 10^{6} T^{-2}-7.7 \\
\approx \delta_{k a O}-\delta_{H 2 O}=\Delta_{\text {min }-\mathrm{H} 2 O}
\end{gathered}
$$

These data, however, are limited in both temperature and composition space. The data used in the derivation of this fractionation is largely empirical and limited by absence of data of directly associated hydrothermal/meteoric water at temperatures measured (Lawrence and Taylor 1979; Marumo et al., 1972). An assumed hydrothermal fluid value is used to derive the majority of $\delta \mathrm{D}$ values used in this fractionation (Marumo et al., 1972), negating temperature and $\delta \mathrm{D}$ effects from mixing and boiling, which decrease the accuracy of calculations (Hurwitz and Lowenstern, 2014). Accordingly, combination of temperature and kaolinite $\mathrm{D} / \mathrm{H}$ data from SI Deep Hole vents with the hydrogen isotopic composition of corresponding vent fluid, allows for a more accurate calculation of kaolinite- $\mathrm{H}_{2} \mathrm{O}$ fractionation. In effect, the vent fluids, their temperature, and coexisting minerals (kaolinite) sampled at Stevenson Island Deep Hole provides a natural laboratory 
that can be used to better constrain kaolinite- $\mathrm{H}_{2} \mathrm{O}$ fractionation for an important and widespread mineral routinely encountered in geothermal system in subaerial and sublacustrine settings.

The recognizable correlation between $\delta^{18} \mathrm{O} / \delta \mathrm{D}$ data for SI Deep Hole fluid samples is indicative of mixing between lake water and steam from a putative vapor source (Fowler et al., 2019c). As emphasized by Fowler et al 2019a, steam addition can be quantified utilizing measured chloride values as a tracer. Conservative mixing can be described as follows:

$$
\text { Mixture }=\mathrm{x} \text { component } \mathrm{A}+(1-\mathrm{x}) \text { component } \mathrm{B}
$$

where $\mathrm{x}$ represents chloride, which can be used in conjunction with enthalpy constraints to then estimate temperature of the mixture. For example, sample YL17F01 (reported in Fowler et al 2019c) has a measured chloride concentration that is $17 \%$ less than that of lake water. Enthalpy calculations show the temperature of this sample $\left(\sim 150^{\circ} \mathrm{C}\right)$ would be produced if $19-22 \%$ saturated steam at $188^{\circ} \mathrm{C}$ (steam saturation temperature estimated for pressure equivalent to that at the lake bottom in the SI Deep Hole region). Hydrogen isotope $(\mathrm{D} / \mathrm{H})$ composition of the steam-lake water mixing fraction estimated from dissolved chloride and enthalpy constrains allow further estimation of the $\mathrm{D} / \mathrm{H}$ composition of the steam source $(\delta \mathrm{D}=-148.1 \%$ ), a value broadly in keeping within the range of values of subaerial fumaroles in Yellowstone National Park (Fowler et al. 2019). This value may be used as an endmember in conjunction with lake water $(-122 \%)$ to account for fluid variability. Evidence of fluid samples characterized by conductive cooling and additional lake water addition are taken into account to provide conditions representative of kaolinite formation (Fig 14). As kaolinite-boehmite sediment collected 


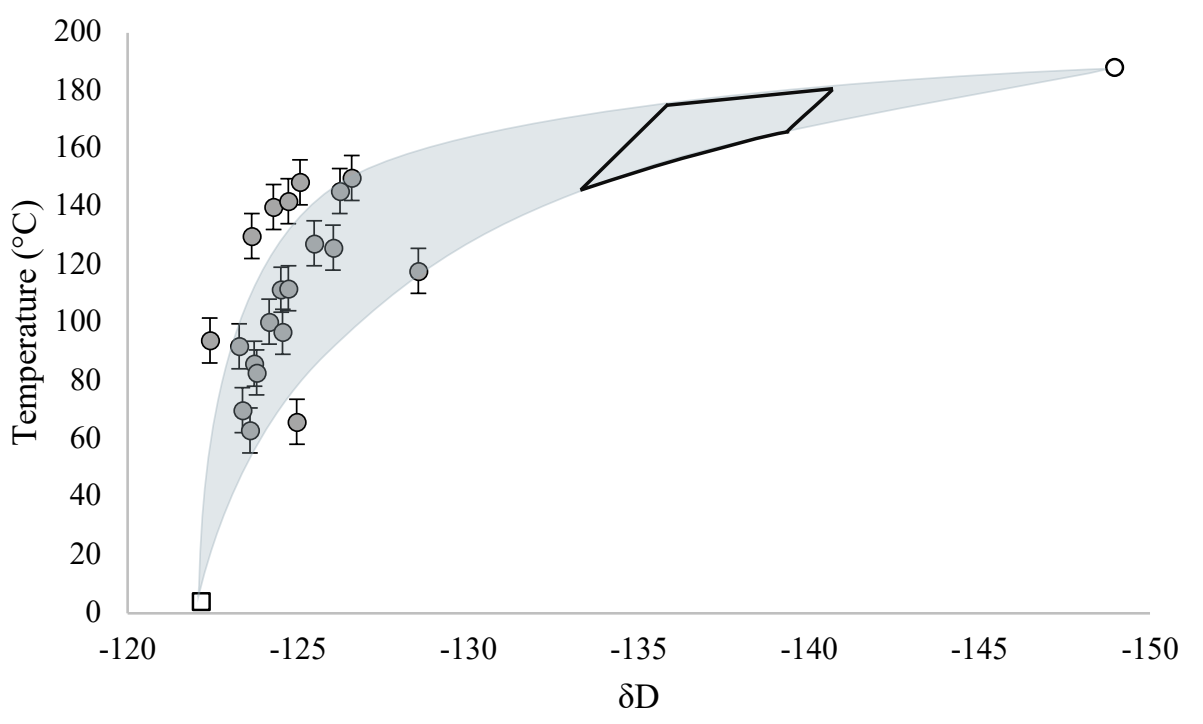

ODeep Hole Measured Fluids

$\square$ Bottom lake water

oDeep Hole Sublacustrine Steam Source (Fowler et al., 2019)

Vent Fluid Mixing Trend

-Kaolinite Formation Zone

Figure 14. Hydrogen isotope fluid variability curve. Correlation of fluid temperature and measured hydrogen isotopic value, determined by steam enthalpy calculations in Fowler et al., 2019a, are representative of conservative mixing between hydrothermally derived steam and bottom lake water and is the top line constrain of the fluid mixing trend. Nonconservative mixing is represented by the best fit lower constrain of the fluid mixing trend. Average variability of measure fluid temperature equates to $7{ }^{\circ} \mathrm{C}$ and is shown in Deep Hole Measured Fluids error bars. Kaolinite Formation Zone that fits within these constrains is calculated by Sheppard and Gilg, 1996 kaolinite fractionation

in SI Deep Hole, show an insignificant difference $( \pm 4 \%$ ) in relation to the kaolinite sample D/H isotopic composition (Y117U02M), it can be assumed that boehmite does not affect $\mathrm{D} / \mathrm{H}$ values or the amount a boehmite within the sample is negligible. Therefore, to best assess kaolinite D/H values, samples YL17U02M and YL17U02B — which due to their position in the core are the most shielded from physical processes-are used to 


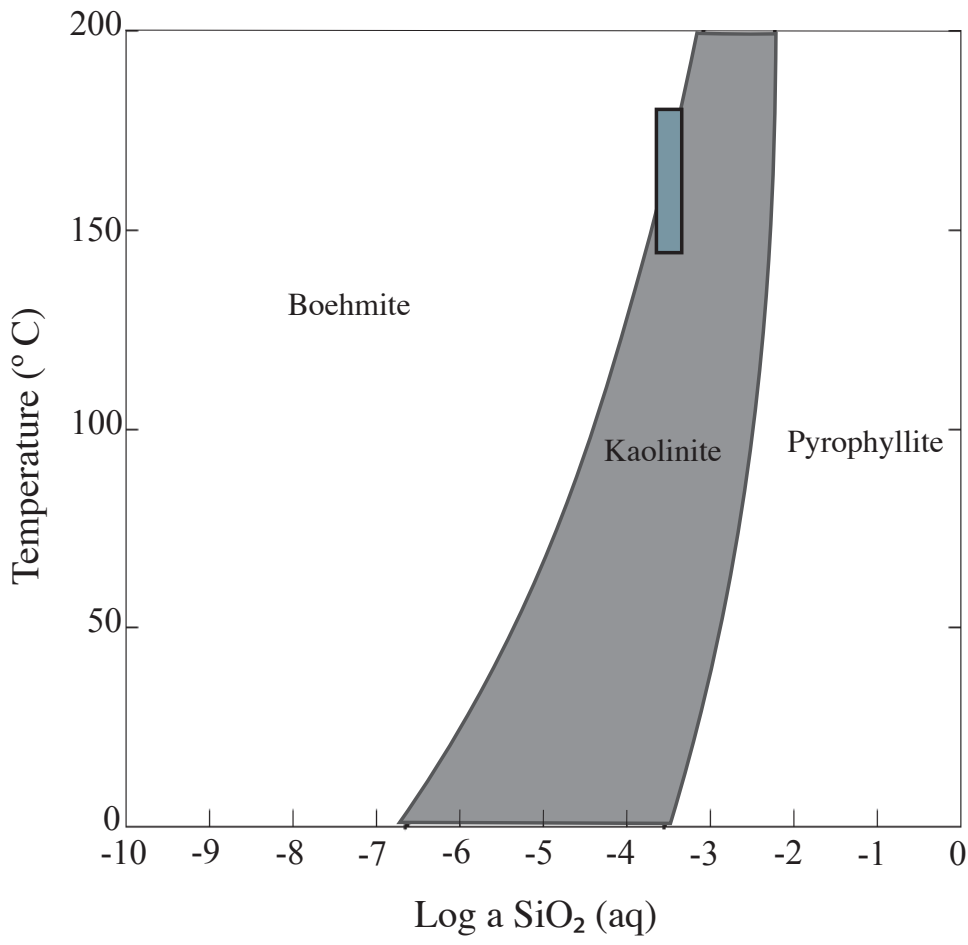

Figure 15. Phase equilibria in the $\mathrm{SiO}-\mathrm{Al2O}-\mathrm{H} 2 \mathrm{O}$ system. The kaolinite and kaolinite-boehmite coexistence is apparent (bar symbol). These phases provide evidence of acid metasomatism and the flux of large amounts of vapor through the sublacustrine Yellowstone Lake hydrothermal system. determine a range of kaolinite formation constraints. Observed vent fluid temperatures $(63-174$ ${ }^{\circ} \mathrm{C}$ ) are used with equation (5) to calculate the kaolinite- $\mathrm{H}_{2} \mathrm{O}$ fractionation factor $(\alpha)$ at the given temperature. This value is then used

with the measured $\delta \mathrm{D}$ composition of kaolinite to infer vent fluid $\delta \mathrm{D}(6)$ (Fig 14).

Temperatures between $\sim 144{ }^{\circ} \mathrm{C}$ to $180^{\circ} \mathrm{C}$ can therefore be suggested as kaolinite formation temperatures as this is where the calculated vent fluid $\delta \mathrm{D}$ correlates with fluid mixing curve. Dissolved silica concentrations of hydrothermal fluids issuing from SI Deep Hole vents are generally consistent with these estimates assuming kaoliniteboehmite-fluid equilibria (Fig. 15) (Fowler et al., 2019a; Fowler et al., 2019c). That the measured vent fluid temperatures, dissolved silica geothermometry, and $\Delta_{\text {(kaolinite-fluid) }}$ data are largely in agreement, lends confidence to the experimental kaolinite-H2O fractionation data reported by Shepard and Gilg (1996). 


\section{CONCLUSION}

The bathymetric structure of the SI Deep Hole system can be linked to hydrothermal alteration of lacustrine sediment, as has been long inferred by others (Shanks et al., 2007). Deep circulating hydrothermal fluids, acidic and reducing, owing to enrichment of $\mathrm{CO}_{2(\mathrm{~g})}$ and $\mathrm{H}_{2} \mathrm{~S}_{(\mathrm{g})}$, respectively, facilitate lacustrine sediment dissolution and volume change. The diatomaceous lacustrine sediment $(\sim 62 \%$ amorphous silica, $22 \%$ smectite, $7 \%$ illite, $6 \%$ albite, $3 \%$ magnetite), when interacted with high temperature $\left(150^{\circ} \mathrm{C}\right)$ silica poor saturated vapor, will transform into a predominately kaolinite substrate, as observed from chemical and mineralogical data. As unaltered sediment ( 4 wt. $\% \mathrm{Al}_{2} \mathrm{O}_{3}$ and 85 wt. $\% \mathrm{SiO}_{2}$ ) comes in contact with hydrothermal fluid it progresses towards a pure kaolinite composition ( 39 wt. $\% \mathrm{Al}_{2} \mathrm{O}_{3}$ and $39 \mathrm{wt} \% \mathrm{SiO}_{2}$ ). Accordingly, the loss of silica parallels total mass loss. Volume can therefore decrease by $\sim 80 \%$. ROV collected cores push cores provide insight into this alteration and the complex fluid networks fueling it. Mineralization progression, as determined by reaction path models, occurs as such: amorphous silica, quartz, smectite, kaolinite, boehmite, increasing in alteration with increase fluid volume. Kinetic considerations, with an assumed flow of $0.001 \mathrm{~kg} / \mathrm{yr}$. in a $1 \mathrm{~kg}$ amorphous silica sample simulate silica polymorph dissolution of this sediment in 3 yrs. Initial progression of this sequence dissolves amorphous silica and quartz, thus, increasing porosity which may subsequently advance fluid flow rate. Accordingly, if the system is defined by high fluid flow rates, boehmite mineralization can be anticipated, as predicted. Thermodynamic considerations may additionally illustrate the dynamic transportation network of fluid through pore space. For example quartz presence in kaolinite substrate is indicative of increased dissolved silica 
concentrations, relative to hydrothermal fluid, which may result from sectional flow loss.

Additionally, the distribution of iron-sulfur mineralization (pyrite and in some case pyrrhotite) also provides evidence of alteration. The complex hydrothermal alteration, therefore, may appear as such:

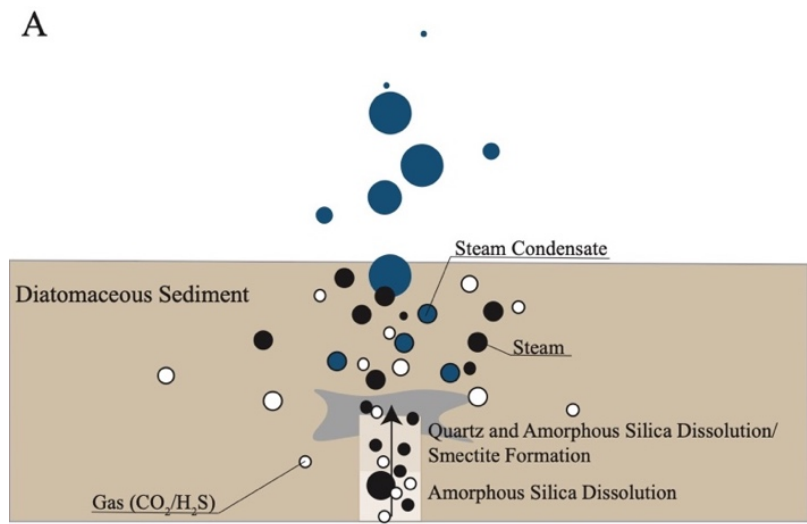

B
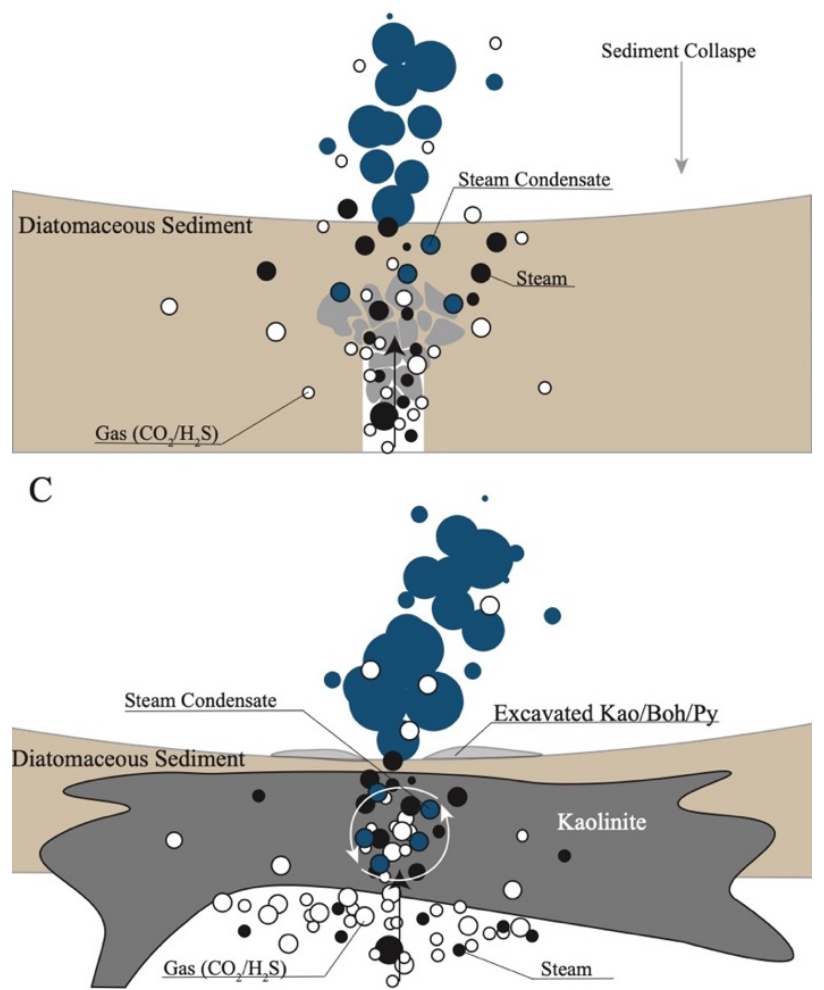

Figure 16. Conceptual Model of SI Deep Hole sediment alteration progression. (A) Initial venting results in amorphous silica dissolution, followed by quartz dissolution and smectite formation. (B) Accordingly as porosity decreases collapse of sediment may occur accounting for brecciated texture and conical depressions due to slumping. (C) Further venting results in a kaolinite dominate sediment, which may thus contain boehmite or smectite and pyrite. 
Deuterium/hydrogen data for kaolinite ( $\delta \mathrm{D}$ values of -152 to $-157 \%$ ) coupled with constraints imposed by coexisting vent fluid data provides an effective means to calculate the magnitude of kaolinite- $\mathrm{H}_{2} \mathrm{O}$ fractionation for conditions observed for the SI Deep Hole vents. This data provides considerations of hydrothermal mixing and boiling that have previously been neglected in $\mathrm{D} / \mathrm{H}$ kaolinite-water fractionation calculations.

The hydrothermal system of Stevenson Island is a dynamic environment, providing insight to processes that may occur deep within subaerial geothermal systems of the Yellowstone Plateaus. By analyzing altered substrate we provide data to construct a narrative of the past for this system. This provides useful as it may have implications to the evolution of similar systems in the park. Additionally, the proximity of this vent system to Mary Bay, one of the largest hydrothermal explosion craters on Earth, suggests addition research and observation is necessary to understand if this active vent system is a hazard to park patrons. 


\section{REFERENCES}

Balistrieri, L.S., Shanks III, W.C., Cuhel, R.L., Aguilar, C. and Klump, J.V. (2007) The influence of sub-lacustrine hydrothermal vent fluids on the geochemistry of Yellowstone Lake.

Bowers, T.S. and Taylor Jr, H.P., 1985. An integrated chemical and stable-isotope model of the origin of midocean ridge hot spring systems. Journal of Geophysical Research: Solid Earth, 90(B14), pp.12583-12606.

Browne, P.R.L. and Ellis, A.J. (1970) The Ohaki-Broadlands hydrothermal area, New Zealand; mineralogy and related geochemistry. American Journal of Science, 269(2), pp.97-131.

Browne, P.R.L. (1978) Hydrothermal alteration in active geothermal fields. Annual review of earth and planetary sciences, 6, pp.229-250.

Bethke, C.M. and Yeakel, S. (2012) The Geochemist'sWorkbench Release 9.0 Reaction modeling guide. Aqueous Solutions. LLC.

Busey, R.H. and Mesmer, R.E. (1977) Ionization equilibriums of silicic acid and polysilicate formation in aqueous sodium chloride solutions to 300.degree.C. Inorganic Chemistry 16, 2444-2450.

Chaffee, M.A., Carlson, R.R. and King, H.D. (2007) Environmental Geochemistry in Yellowstone National Park: Natural and Anthropogenic anomalies and their potential impact on the environment, in: Morgan, L.A. (Ed.), Integrated Geoscience Studies in the Greater Yellowstone Area: Volcanic, Hydrothermal and Tectonic Processes in the Yellowstone Geoecosystem. U.S. Geological Survey Professional Paper (in press).

Christiansen, R. L. (1984) Yellowstone magmatic evolution: its bearing on understanding large-volume explosive volcanism. In Studies in Geophysics: Explosive Volcanism: Inception, Evolution, and Hazards, pp. 84-95. Washington, DC: Natl. Acad. Press

Christiansen, R.L., (2001) The quaternary and Pliocene Yellowstone Plateau volcanic field of Wyoming, Idaho, and Montana (No. 729-G).

Christiansen, R.L., Lowenstern, J.B., Smith, R.B., Heasler, H., Morgan, L.A., Nathenson, M., Mastin, L.G., Muffler, L. and Robinson, J.E., (2007) Preliminary assessment of volcanic and hydrothermal hazards in Yellowstone National Park and vicinity. U. S. Geological Survey.

Fisher, A.T. and Underwood, M.B. (1995) Calibration of an X-ray diffraction method to determine relative mineral abundances in bulk powders using matrix singular value decomposition: a test from the Barbados accretionary complex. In Proceedings of the Ocean Drilling Program. Part A, Initial report (Vol. 156, pp. 29-37).

Fournier, R.O. and Rowe, J.J. (1977) The solubility of amorphous silica in water at high temperatures and high pressures. Am. Mineral. 62, 1052-1056.

Fournier, R.O. (1989) Geochemistry and Dynamics of the Yellowstone National Park Hydrothermal System. Ann. Rev. Earth Planet. Sci. 17, 13-53. 
Fowler, A.C., Tan, C., Cino, C.D., Scheuermann, P., Volk, M.W.R., Shanks III, W.C. and Seyfried,W.E., Jr. (2019a) Vapor-driven sublacustrine vents in Yellowstone Lake, Wyoming. Geology (Boulder) 47, 223-226.

Fowler, A.P.G., Liu, Q.-1., Huang, Y., Tan, C., Volk, M.W.R., Shanks, W.C.P. and Seyfried, W.(2019b) Pyrite $\delta 34 S$ and $\Delta 33$ S constraints on sulfur cycling at sublacustrine hydrothermal vents in Yellowstone Lake, Wyoming, USA. Geochem. Acta 265, 148-162.

Fowler, A.P.G., Tan, C., Luttrell, K., Tudor, A., Scheuermann, P., Pat Shanks, W.C. and Seyfried,W.E. (2019c) Geochemical heterogeneity of sublacustrine hydrothermal vents in Yellowstone Lake, Wyoming. J. Volcano. Geotherm. Res. 386, 106677, doi:10.1016/j.jvolgeores.2019.106677

Grant, J.A. (2005) Isocon analysis: A brief review of the method and applications. Physics and Chemistry of the Earth, Parts A/B/C, 30(17-18), pp.997-1004.

Grenthe, I., Stumm, W., Laaksuharju, M., Nilsson, A.C. and Wikberg, P. (1992) Redox potential and redox reaction in deep groudwater systems. Chem. Geol. 98, 131150.

Gunnarsson, I. and Arnorsson, S. (2000) Amorphous silica solubility and the thermodynamic properties of $\mathrm{H} 4 \mathrm{SiO} 4$ degrees in the range of 0 degrees to 350 degrees C at P-sat. Geochim. Cosmochim. Acta 64, 2295-2307.

Hafner, B., Energy Dispersive Spectroscopy on the SEM:A Primer, http://www.charfac.umn.edu/instruments/eds_on_sem_primer.pdf

Hedenquist, J.W. and Henley, R.W. (1985) Hydrothermal eruptions in the Waiotapu geothermal system, New Zealand; their origin, associated breccias, and relation to precious metal mineralization. Economic geology, 80(6), pp.1640-1668.

Hedenquist, J.W. (1990) The thermal and geochemical structure of the BroadlandsOhaaki geothermal system, New Zealand. Geothermics, 19(2), pp.151-185.

Huang, H.-H., Lin, F.-C., Schmandt, B., Farrell, J., Smith, R.B. and Tsai, V.C. (2015) The Yellowstone magmatic system from the mantle plume to the upper crust. Science 348, 773-776.

Hurwitz, S. and Lowenstern, J.B., (2014) Dynamics of the Yellowstone hydrothermal system. Reviews of Geophysics, 52(3), pp.375-411

Hurwitz, S., Clor, L.E., McCleskey, R.B., Nordstrom, D.K., Hunt, A.G. and Evans, W.C. (2016) Dissolved gases in hydrothermal (phreatic) and geyser eruptions at Yellowstone National Park, USA. Geology, 44(3), pp.235-238.

Jackson, M., Solheid, P., 2010. On the quantitative analysis and evaluation of magnetic hysteresis data, Geochemistry Geophysics Geosystems 11, Q04Z15, doi:10.1029/2009GC002932.

Johnson, J.W., Oelkers, E.H. and Helgeson, H.C. (1992) SUPCRT92 - A software package for calculating the standard molal thermodynamic properties of minerals, gases, aqueous species, and reactions from 1-bar to 5000 -bar and $0^{\circ} \mathrm{C}$ to $1000^{\circ} \mathrm{C}$. Comp. Geosci. 18, 899-947.

Johnson, S.Y., Stephenson, W.J., Morgan, L.A., Shanks III, W.C. and Pierce, K.L. (2003) Hydrothermal and tectonic activity in northern Yellowstone Lake, Wyoming. Geological Society of America Bulletin, 115(8), pp.954-971.

Koel, T. (2010) Yellowstone Fisheries and Aquatic Sciences Report 2009-2010. National 
Park Service: Yellowstone National Park.

Kong, X.-Z., Tutolo, B.M. and Saar, M.O. (2013) DBCreate: A SUPCRT92-based program for producing EQ3/6, TOUGHREACT, and GWB thermodynamic databases at user-defined T and P. Comput. Geosci. 51, 415-417.

Lasaga, A.C. (1995) Fundamental approaches in describing mineral dissolution and precipitation rates, in: White, A.F., Brantley, S.L. (Eds.), Chemical Weathering Rates of Silicate Minerals. Mineralogical Society of America, pp. 23-86.

Montanaro, C., Scheu, B., Gudmundsson, M.T., Vogfjörd, K., Reynolds, H.I., Dürig, T., Strehlow, K., Rott, S., Reuschlé, T. and Dingwell, D.B. (2016) Multidisciplinary constraints of hydrothermal explosions based on the 2013 Gengissig lake events, Kverkfjöll volcano, Iceland. Earth and Planetary Science Letters, 434, pp.308319.

Morgan, L.A., Shanks Iii, W.C., Lovalvo, D.A., Johnson, S.Y., Stephenson, W.J., Pierce, K.L., Harlan, S.S., Finn, C.A., Lee, G., Webring, M., Schulze, B., Dühn, J., Sweeney, R. and Balistrieri, L. (2003) Exploration and discovery in Yellowstone Lake: results from high-resolution sonar imaging, seismic reflection profiling, and submersible studies. J. Volcanol. Geotherm. Res. 122, 221-242.

Morgan, L.A. and Shanks, W.C., III (2005) Influences of rhyolitic lava flows on hydrothermal processes in Yellowstone Lake and on the Yellowstone Plateau, in: Inskeep, W.P., McDermott, T.R. (Eds.), Geothermal Biology and Geochemistry in Yellowstone National Park. Thermal Biology Institute, Montana State University, Bozeman, MT.

Morgan, L.A., Shanks III, W.C., Pierce, K.L., Lovalvo, D.A., Lee, G.K., Webring, M.W., Stephenson, W.J., Johnson, S.Y., Harlan, S.S., Schulze, B. and Finn, C.A. (2007a) The floor of Yellowstone Lake is anything but quiet-New discoveries from high-resolution sonar imaging, seismic-reflection profiling, and submersible studies.

Morgan, L.A., Shanks, W.C., Lee, G.K. and Webring, M.W. (2007b) Bathymetry and geology of the floor of Yellowstone Lake, Yellowstone National Park, Wyoming, Idaho, and Montana (No. 2973). US Geological Survey, doi:10.3133/sim2973

Morgan, L.A., Cathey, H.E. and Pierce, K.L. (2009a) The Track of the Yellowstone Hotspot: Multi-disciplinary Perspectives on the Origin of the Yellowstone-Snake River Plain Volcanic Province. J. Volcanol. Geotherm. Res. 188, v-vi.

Morgan, L.A., Shanks, W.C. and Pierce, K.L., (2009b) Hydrothermal processes above the Yellowstone magma chamber: Large hydrothermal systems and large hydrothermal explosions (Vol. 459). Geological Society of America.

Oyedotun, T.D.T., 2018. X-ray fluorescence (XRF) in the investigation of the composition of earth materials: a review and an overview. Geology, Ecology, and Landscapes, 2(2), pp.148-154, doi:10.1080/24749508.2018.1452459

Pierce, K. L. and Morgan, L. A. (1992) The track of the Yellowstone hot spot: Volcanism, faulting, and uplift. Regional Geology of Eastern Idaho and Western Wyoming: Geological Society of America Memoir. 179, 1-53.

Pierce, K.L. and Morgan, L.A. (2009) Is the track of the Yellowstone hotspot driven by a deep mantle plume? - Review of volcanism, faulting, and uplift in light of new data. J. Volcanol. Geotherm. Res. 188, 1-25. 
Poppe, L.J., Paskevich, V.F., Hathaway, J.C. and Blackwood, D.S., 2001. A laboratory manual for X-ray powder diffraction. US Geological Survey open-file report, 1(041), pp.1-88.

Raharjo, I.B., Allis, R.G. and Chapman, D.S. (2016) Volcano-hosted vapor-dominated geothermal systems in permeability space. Geotherm. 62, 22-32.

Rimstidt, J.D. and Barnes, H. (1980) The kinetics of silica-water reactions. Geochim. Cosmochim. Acta 44, 1683-1699.

Rowe, J.J., Fournier, R.O. and Morey, G.W., (1973) Chemical analysis of thermal waters in Yellowstone National Park, Wyoming, 1960-65 (No. 1303-1305). US Government Printing Office.

Schubert, G., Straus, J.M. and Grant, M.A. (1980) A problem posed by vapourdominated geothermal systems. Nature 287, 423-425.

Shanks, W.C., III, Alt, J.C. and Morgan, L.A. (2007) Geochemistry of sub lacustrine hydrothermal deposits in Yellowstone Lake: Hydrothermal reactions, stable isotope systematics, sinter deposition, and spire growth, in: Morgan, L.A. (Ed.), Integrated geoscience studies in the greater Yellowstone area: Volcanic, tectonic, and hydrothermal processes in the Yellowstone geoecosystem. U. S. G. S. Professional Paper, pp. 201-234.

Sheppard, S.M.F. and Gilg, H.A., 1996. Stable isotope geochemistry of clay minerals. Clay minerals, 31(1), pp.1-24, doi:10.1016/0016-7037(95)00417-3

Simmons, S.F. and Browne, P.R. (2000) Hydrothermal minerals and precious metals in the Broadlands-Ohaaki geothermal system: Implications for understanding lowsulfidation epithermal environments. Economic Geology, 95(5), pp.971-999.

Sohn, R., Harris, R., Linder, C., Luttrell, K., Lovalvo, D., Morgan, L., Seyfried Jr., W.E.,Shanks III, W.C., (2017) Exploring the restless floor of Yellowstone Lake. Eos, 98.

Sohn, R.A., Luttrell, K., Shroyer, E., Stranne, C., Harris, R.N. and Favorito, J.E. (2019) Observations and modeling of a hydrothermal plume in Yellowstone Lake. Geophysical Research Letters, 46(12), pp.6435-6442.

Stefansson, A., Amorsson, S. and Sveinbjornsdottir, A.E. (2005) Redox reactions and potentials in natural waters at disequilibrium. Chem. Geol. 221, 289-311.

Stumm, W. and Morgan, J. (1996) Aquatic Chemistry, John Wiley \& Sons. New York.

Tan, C., Cino, C.D., Ding, K. and Seyfried, W.E. (2017) High temperature hydrothermal Vent fluids in Yellowstone Lake: Observations and insights from in-situ $\mathrm{pH}$ and redox measurements. J. Volcano. Geotherm. Res. 343, 263-270.

Thermo Scientific (2010). Thermo Scientific High Temperature Conversion Elemental Analyzer: User manual. Retrieved from https://assets.thermofisher.com/TFSAssets/CMD/brochures/BR-30034-IRMS-Temperature-Conversion-EABR30034-EN.pdf

Truesdell, A.H. and White, D.E. (1973) Production of superheated steam from vapordominated geothermal reservoirs. Geotherm. 2, 154-173. 
Tutolo, B.M., Kong, X.Z., Seyfried, W.E. and Saar, M.O. (2014) Internal consistency in aqueous geochemical data revisited: Applications to the aluminum system. Geochim. Cosmochim. Acta 133, 216-234.

White, D. E., Fournier, R.O., Muffler, L. J. P., and Truesdell, A. H. (1975) Physical results of research drilling in thermal areas of Yellowstone National Park, Wyoming. USGS Prof Pap. 892, 1- 70.

Zhang, D., Wang, Y., Zhang, W., Pan, J. and Cai, J. (2011) Enlargement of diatom frustules pores by hydrofluoric acid etching at room temperature. Journal of Materials Science - J MATER SCI 46, 5665-5671. 


\section{APPENDIX}

Table A.1. Sampling and Analyzation Procedures

\begin{tabular}{|c|c|c|c|}
\hline Sample & Depth $(\mathbf{c m})$ & Description & Sampling Procedure \\
\hline YL17U01 & 5.3 & Vent 2 Throat & $\begin{array}{l}\text { Bulk sediment sample analyzed by XRD, ICP-MS, ICP-OES and additionally measured for } \mathrm{SO}_{3}{ }^{-} \\
\text {by XRF, water content and D/H isotope by IRMS. Separated coarse sediments analyzed by SEM. }\end{array}$ \\
\hline YL17U02T & 1 & $1 \mathrm{~m}$ Offset Vent 2 Top Sediment & $\begin{array}{l}\text { Bulk sediment sample analyzed by XRD, ICP-MS, ICP-OES and additionally measured for } \mathrm{SO}_{3}{ }^{-} \\
\text {by XRF, water content and D/H isotope by IRMS. Separated coarse sediments analyzed by SEM. }\end{array}$ \\
\hline YL17U02M & 10.8 & $1 \mathrm{~m}$ Offset Vent 2 Middle Sediment Kaolinite Reference & $\begin{array}{l}\text { Fine grain separated sediment analyzed by } \mathrm{XRD}, \mathrm{XRF} \text {, and water content and } \mathrm{D} / \mathrm{H} \text { isotope by } \\
\text { IRMS. }\end{array}$ \\
\hline YL17U02B & 21.8 & $1 \mathrm{~m}$ Offset Vent 2 Bottom Sediment & $\begin{array}{l}\text { Bulk sediment sample analyzed by XRD, ICP-MS, ICP-OES and additionally measured for } \mathrm{SO}_{3}^{-} \\
\text {by XRF, water content and D/H isotope by IRMS. Separated coarse sediments analyzed by SEM. }\end{array}$ \\
\hline YL1703I & 17.7 & Vent 1 Throat & $\begin{array}{l}\text { Bulk sediment sample analyzed by XRD, ICP-MS, ICP-OES and additionally measured for } \mathrm{SO}_{3}^{-} \\
\text {by XRF, water content and D/H isotope by IRMS. Separated coarse sediments analyzed by SEM. }\end{array}$ \\
\hline YL17U04T & 1 & $1 \mathrm{~m}$ Offset Vent 1 Top Sediment & $\begin{array}{l}\text { Bulk sediment sample analyzed by XRD, ICP-MS, ICP-OES and additionally measured for } \mathrm{SO}_{3}^{-} \\
\text {by XRF, water content and D/H isotope by IRMS. Separated coarse sediments analyzed by SEM. }\end{array}$ \\
\hline YL17U04B & 15.4 & $1 \mathrm{~m}$ Offset Vent 1 Bottom Sediment & $\begin{array}{l}\text { Bulk sediment sample analyzed by XRD, ICP-MS, ICP-OES and additionally measured for } \mathrm{SO}_{3}^{-} \\
\text {by XRF, water content and D/H isotope by IRMS. Separated coarse sediments analyzed by SEM. }\end{array}$ \\
\hline YL17U05 & 18.5 & Reference $30 \mathrm{~m}$ Away Sediment & $\begin{array}{l}\text { Bulk sediment sample analyzed by XRD, ICP-MS, and ICP-OES. Separated coarse sediments } \\
\text { analyzed by SEM. }\end{array}$ \\
\hline
\end{tabular}




\section{Sediment Dissolution Procedure}

Sediments were dissolved to analyze by ICP-MS and ICP-OES. Custom-made Teflon vials are prepared with magnetic stir rods and $100 \mathrm{mg}$ of powdered sediment. Vials are placed into titanium housing to prevent spillage. Concentrated trace-metal grade acid-4 $\mathrm{ml} \mathrm{HNO}_{3}, 1.5 \mathrm{ml} \mathrm{HCl}, 1.5 \mathrm{ml} \mathrm{HF}$ - is then injected into each vial with the addition of $1 \mathrm{ml} 18 \mathrm{M} \Omega$ water. Teflon caps with O-ring addition are placed on the vials. Titanium plates are positioned on top of the Teflon caps and tighten by screws. The custom-made titanium asher system is then placed in an oven at $200{ }^{\circ} \mathrm{C}$ for 2 hours. Upon removal, while system is cooling, screws are tightened periodically to ensure seal. When cool to the touch, vials are opened and post digestion addition of $12 \mathrm{ml} 4 \mathrm{wt} \% \mathrm{H}_{3} \mathrm{BO}_{3}$ and $10 \mathrm{ml} 18 \mathrm{M} \Omega$ water is added and solution is stirred. Solution is then pipetted into Teflon bottles and placed in the oven overnight to ensure full dissolution. 